\title{
Naturaleza y cultura en los rituales de San Antonio
}

\author{
Nature and Culture in the Rituals \\ of San Antonio
}

\author{
Honorio M. Velasco Má1lo \\ UNED, Madrid
}

\section{RESUMEN}

En este artículo reflexiono en torno al culto de San Antonio Abad o San Antón como una muestra de la fusión naturaleza y cultura a través de los ritos que llevan a cabo las distintas poblaciones que festejan a este santo. Las prácticas festivas de este "santo viejo" están asociadas a prácticas precristianas relacionadas con el culto al fuego y la protección de los animales. El culto de este santo popular estuvo muy extendido por Europa y fue exportado a las colonias americanas. Sirve como expresión muy clara de cómo las apropiaciones populares se han producido una y otra vez estimuladas por iniciativas eclesiásticas y se han desarrollado según los modos propios las prácticas propuestas, rozando en ocasiones la heterodoxia y expresando mecanismos de resistencia al cambio. Aunque por otra parte este culto se ha mantenido gracias a que se ha adaptado; el campo se industrializó y dejó de celebrarse la bendición de animales para pasar a bendecir las máquinas. Cuando prácticamente se ha abandonado la explotación ganadera, el culto se adapta a la nueva sensibilidad ecológica y se bendicen las mascotas. San Antonio concilia naturaleza y cultura, lo rural con lo urbano, los cultos remotos con la nueva ecología.

Palabras clave: Fiestas populares; Naturaleza; Cultura; Culto del fuego; Bendición de Animales.

\section{SUMMARY}

In this paper I analyze the cult of San Antonio Abad, San Antón, as an example of the ritual fusion of nature and culture in the different communities commemorating this Saint. The festive practices of this "old Saint" are associated to preChristian rites related to fire and the protection of animals. The cult to this Saint was very pread out in Europe, and was even exported to the American colonies. It is a clear example of how popular practices appropriate Church initiatives within their own logic, bordering het- 
erodoxy at times, while expressing mechanisms of resistance to change. Yet it is clear that this cult has survived because it has adapted. When industrialization came to the countryside, the animal blessing gave way to machine blessing. When stockbreeding is on the wane, the cult adjusts to new ecological sensibilities and the blessings go to pets. St. Antonio unifies nature and culture, rural and urban, remote cults with ecology.

Key Words: Holidays; Nature; Culture; Fire Rituals; Animals Rituals.

\section{INTRODUCCIÓN. UN SANTO VIEJO}

San Antonio, San Antonio Abad, San Antonio de Enero o San Antón, son todas denominaciones extendidas de un santo al que se venera en numerosas poblaciones en España y en Europa y que es tenido como un "santo viejo". La caracterización de "viejo" es peculiar y deben ser tomados en consideración sus varios sentidos. Se refiere, por un lado, a que la iconografía suele comúnmente mostrar una figura de monje "viejo", aunque no estrictamente anciano, especialmente en las escenas de desierto. Por otro lado, está integrado dentro de lo que se podría tomar como el estrato antiguo de santos de devoción cristiana bien enraizado en la religiosidad popular pero posteriormente postergado por devociones a otros santos, promovidas por órdenes religiosas con creciente presencia social o fomentadas por los prelados en sus respectivas diócesis o cumpliendo normas provenientes de la Santa Sede. La historia de las devociones populares es una historia de desplazamientos de objetos de devoción hacia unas u otras figuras de santos o advocaciones cristológicas o marianas (Christian 1991).

Tal vez mucho más viejas que la propia referencia cristiana que el santo proporciona sean las prácticas festivas asociadas al santo que se suponen procedentes de celebraciones paganas anteriores. Consualia romana, los cultos Beltane celtas, como sugería Frazer (1922). Y aún cabe imaginar que si entre esas prácticas se encuentra el culto al fuego éste pudiera ser más antiguo que los paganismos conocidos. Indefinidamente antiguo. Es más que probable, sin embargo, que la celebración a este santo no sea la única que haya recogido los cultos al fuego (o del fuego) pues es sabido que prácticas rituales con tratamientos variados del fuego están muy repartidas a lo largo del año, bastante más que en relación con las transiciones solsticiales o equinocciales. Inevitablemente salta aquí la cuestión de las supervivencias y se cruza con la siempre mal tapada irrupción del paganismo en los cultos cristianos. Pero ambas cuestiones no pueden ser resueltas tan sólo con las referencias en torno a una manifestación festiva como ésta y han de dejarse una vez más en suspenso.

Aunque en los cultos a San Antonio se acumulan varias prácticas - y se verá después más detenidamente- como las hogueras y la integración so- 
cial de los animales. No los hace demasiado singulares pero ciertamente les corresponde la intersección entre "naturaleza y cultura" que se recoge en el título de este trabajo. No porque quiera ser una afiliación estructuralista muy común hace algún tiempo, sino porque efectivamente las prácticas parecen moverse entre esos grandes ámbitos traspasando de uno a otro atributos, cualidades y sentidos.

Los materiales etnográficos son muy abundantes. No sólo con referencias sobre fiestas y tradiciones en poblaciones españolas, sino también italianas, francesas, portuguesas y europeas (además de las americanas, especialmente en los países que fueron colonias españolas con misiones de frailes antonianos). Y habría que añadir un volumen considerable de ilustración literaria eclesiástica y de ilustraciones gráficas en pintura y escultura, pues el santo, su vida y milagros han sido tema frecuentado por el arte a lo largo de la historia.

San Antonio es un santo muy popular y sobre él cabe admitir que se ha focalizado de forma muy acusada la religiosidad popular. Su culto sirve como expresión muy clara de cómo las apropiaciones populares se han producido una y otra vez estimuladas por iniciativas eclesiásticas y se han desarrollado según los modos propios las prácticas propuestas, aunque eso suponga frecuentemente derivas luego consideradas heterodoxas o inapropiadas. En ocasiones pueden haber sido tenidas como resistentes a las innovaciones por mantener otras más antiguas. Es el caso de algunas de las prácticas asociadas a este santo, como la representación del cerdo junto al santo en las imágenes, las entradas de los animales, las danzas y representaciones en recinto sagrado y con diablos, la bendición del fuego o los saltos sobre él, etc. No pocas veces estas prácticas han sido mencionadas expresamente en las prohibiciones reflejadas en Sínodos o en las recomendaciones y mandatos que aparecen en los informes de las Visitas episcopales.

La "popularidad" del santo implica prácticas y creencias diversas y entre ellas un tratamiento de familiaridad que muy expresivamente trasmiten las coplas tan abundantes que se cantan en torno a la fiesta, pero también todo el discurso común que se intercambia en ella. Tan reveladora familiaridad se casa difícilmente con la gravedad de la representación iconográfica (un santo asceta, heroico por haber sobrevivido al desierto) y con los valores formalmente atribuidos a las imágenes y advocaciones religiosas.

Del mismo modo y en relación de polaridad también se ha hecho "popular" en este caso (y en algunos otros) la incorporación de las figuras de los demonios al culto y a la celebración festiva, en una dirección bastante diferente de la presencia que tiene en el arte religioso. Relacionados o no con el culto al fuego, los demonios "andan sueltos" por el ritual justificando transgresiones. 
Es reconocido que la fiesta tuvo sus tiempos álgidos en las poblaciones rurales antes de la industrialización del campo y muy generalmente se ha destacado que estaba llamada a desaparecer porque la reducción de los animales de trabajo y transporte en las áreas rurales llevó comúnmente a pensar que el santo se había ido quedando sin "oficio", aun cuando en algún pueblo se mantuviera la fiesta cambiando la bendición de animales por la bendición de maquinaria agrícola.

Pero es tal vez sorprendentemente una fiesta resucitada. Por doble proceso. Las mismas poblaciones que la abandonaron, más tarde la hicieron revivir, animada por un impulso revitalizador de tradiciones perdidas en busca casi siempre de aliento para una identidad necesitada de revigorización. Y por otra parte, resucitada con la incorporación de un nuevo objeto de la protección del santo, los animales de compañía (urbanos casi todos ellos), tan extremadamente variados en su especie como variada es la intención de los dueños en hacerlos desfilar, mientras el celo eclesiástico estimula su acogida en la iglesia (el entorno de la iglesia) como un programa de acomodación a los nuevos tiempos. De los animales-útiles a los animales-adorno, San Antón no parece haber cambiado demasiado de oficio.

Y de esta forma imprevista la fiesta liga las referencias más viejas a supervivencias de pasados remotos a las modernas compañías de la soledad urbana, relaciona las viejas cofradías con las sociedades protectoras de animales y dibuja una continuidad entre la tradicional explotación ganadera y la creciente sensibilidad ecológica y de defensa de la diversidad biológica.

San Antonio no sólo hace interseccionar "naturaleza y cultura", sino también lo santo y lo demoníaco, lo rural y lo urbano, el culto al fuego remoto y la nueva sensibilidad ecológica.

\section{MOTIVOS HAGIOGRÁFICOS Y MOTIVOS ICONOGRÁFICOS}

El culto a San Antonio por popular que pueda llegar a ser tiene como referencia una serie de motivos proporcionados y difundidos desde las hagiografías eclesiásticas a partir de una primera fuente que por otra parte es primera en la serie de Vitae de santos, de tanta influencia en la formación y desarrollo de la devoción medieval: la Vita Antonii de San Atanasio. Ésta es a su vez la fuente principal de la que se reprodujo en La leyenda dorada de Santiago de la Vorágine (s. XIV). Y comparada en cuanto a sus contenidos la hagiografía de San Antonio que aparece en ella con otras de los numerosos santos que llegaron a tener una fuerte devoción resulta más próxima a los cánones eclesiásticos de santidad que a los que se suponen populares. Los motivos que en La leyenda dorada aparecen son: 
- Fue anacoreta en el desierto, tras vender sus posesiones y donarlas a los menesterosos, movido por la predicación del Evangelio: "Si quieres ser perfecto, vende tus bienes, etc."

- Presentó una firme resistencia a las tentaciones del demonio que de forma continuada asedió, presionó, halagó, torturó al santo. Los motivos reflejan en concreto las tentaciones en relación con: el deseo de fornicación, el dolor físico, la muerte aparente, la riqueza en forma de tesoros hallados, la ambición de poder en un mundo enmarañado, las dificultades e impedimentos para lograr el éxtasis, la confrontación directa con el propio demonio presentándosele como un gigante de corpulencia enorme.

- Fue un modelo para los monjes: observancia fiel de las prácticas de penitencia, retiro a las celdas duradero y sin concesiones, desprendimiento total de los bienes, superación del desaliento y el tedio, visiones del futuro (la herejía arriana), valentía en su postura de denuncia de los tiranos.

- En la historia de San Pablo ermitaño se narran además los siguientes acontecimientos:

- Creyendo que era el único anacoreta, mientras duerme sabe que hay otro en el mismo desierto más antiguo que él y va en su busca. Primero se encuentra a un ser mitad hombre, mitad caballo que le indica el camino hacia la derecha, luego a uno mitad hombre, mitad cabra y que tiene en su mano un puñado de dátiles y dice ser un sátiro, y después a un lobo que le conduce a la celda del otro.

- Pablo primero no le quiere ver ni recibir y ante la insistencia de Antonio lo hace; el cuervo les trae dos panes; discuten sobre quién debe bendecir y partir el pan que finalmente tirando cada uno de un lado se divide:

- Se volvía Antonio cuando ve pasar el alma de Pablo, vuelve, encuentra el cuerpo muerto rezando y lo entierra con ayuda de los leones; se lleva la túnica hecha de cortezas y ramas de palmera que se pondrá los días de fiesta.

Según Peter Brown (1988) es una hagiografía construida tomando como modelo a San Juan Bautista, prototipo de un héroe especial, el santo, y dentro de éstos, el asceta que ayunaba, rezaba y disciplinaba su carne en el desierto.

La polaridad entre el santo y los demonios ha llegado a formar parte sustantiva de la "imagen" del santo, de modo que, como se ha recogido en la historiografía medievalista, la hagiografía debe ser tomada a la vez como un tratado de demonología y en ese sentido José María Blázquez (1998) ha desglosado los motivos de ésta: 
- Las denominaciones empleadas son: diabolus, inimicus, subdolus, peccator y tyrannus.

- El demonio proporcionaba castigos y males físicos a los cristianos.

- Generaba gran susto y terror mediante la aparición de bestias salvajes: leones, osos, leopardos, serpientes, toros, áspides, escorpiones, lobos (antes sólo o predominantemente se hacía presente con serpientes o dragones). Como se verá, éste es el motivo favorito de las representaciones pictóricas de "las tentaciones". Con cierta ambigüedad se toma este motivo como fundamento del patronazgo sobre los animales domésticos. O bien otra racionalización justifica que esta victoria contra el demonio en sus manifestaciones bestiales le da el patronazgo sobre todos los animales. $\mathrm{O}$ es que los principales males que sobrevienen a los animales domésticos proceden de las bestias salvajes, etc.

- Como sonido revelador de su presencia: el chirriar de dientes.

- Pero Antonio muestra no obstante que, pese al impacto, tales apariciones no son más que fantasmas, ficciones, engaños.

- Del demonio procede la tentación del deseo de fornicar.

- Los que le visitaban no veían a los demonios, aunque los oían.

- Le protegía la cruz y los rezos.

- Simulan profetizar el futuro.

- Engañan manifestándose como buenas gentes o incluso eremitas o como ángeles o el mismo Cristo.

- Como pan, como luces de noche,...

- De cuerpo altísimo y muy ancho.

- Antonio da criterios para distinguirlos: producen temblor, agitación, pensamientos desordenados, tristeza, temor a la muerte, deseo de mal, somnolencia..., huelen mal, son negros, de aspecto terrible.

- Merodeaban por el desierto, y habitaban en el aire (ésta era una creencia que se halla en el Helenismo y había sido adoptada por los primeros cristianos).

- La imagen del gigante que capta algunas almas que suben al cielo, mientras que otras buenas se libran se vale de imágenes anteriores de almas aladas que son paganas y del gigante atrapándolas, que debe ser egipcia.

- Antonio acepta la creencia de que los dioses paganos son demonios.

Motivos hagiográficos que serán complementados más tarde con otros de procedencia no identificada pero que recogen las hagiografías barrocas:

- Traslado de las reliquias en el Viennois. Leyenda sobre Jocelin señor de La Motte-Saint-Didier sobre una peregrinación no cumplida a 
Tierra Santa, aparición en visión como viejo venerable y hallazgo de reliquias en Alejandría, después trasladadas a Francia.

- Curación de una jabalina ciega y tullida, en una supuesta visita que hiciera el santo a Cataluña llamado por los Condes de Barcelona.

- Curaciones de la enfermedad del cornezuelo de centeno, entre ellas la de Guerin, hijo del noble Gastón.

- Labor de los antonianos atendiendo a los apestados y fogardientados.

Los tratamientos iconográficos son en parte los apuntados y en parte otros. En los iconos orientales el santo se muestra haciendo vida ascética en el desierto, a veces acompañado de San Pablo o bien como patrono de la propia vida ascética y fundador de monasterios de monjes.

Pero en las tradiciones de pintura y escultura en Occidente se fue formando y luego desarrollando una doble representación. La primera como imagen canónica en esculturas de bulto y en pinturas de devoción y estampas con una serie de motivos con los que se consigue una identificación precisa. La segunda, casi exclusivamente en pintura, religiosa en apariencia pero también profana por trasgresión, que recrea "las tentaciones" y explora en la polaridad santos-demonios descubriendo en ella una enorme fuerza expresiva.

Esta segunda bebe en las fuentes hagiográficas primeras. Al menos aparentemente. Es la línea de representaciones en torno a las "Tentaciones de San Antonio", uno de esos conjuntos de motivos iconográficos clásicos que ha pasado del arte religioso al laicismo moviéndose más allá de la devoción para asomarse al abismo de los deseos, a las oscuras profundidades de la mente o al sustrato cenagoso de la condición humana. De El Bosco a Dalí, las "Tentaciones" cobran formas y colores impactantes borrando casi la presencia del santo. Muy a menudo los demonios muestran su impresionante capacidad de trasformismo y frecuentemente adoptan la figura de mujer desnuda. La Vita de San Atanasio decía también que los demonios se disfrazaban de otros ermitaños, de modo que cabe pensar que este motivo ha sido un buen pretexto para hacer de la visibilidad del mal una trasgresión. Por otro lado, el muestrario de demonios en sus formas animales habitualmente se llena de figuras monstruosas seguramente irreales antes de encontrar realidad dentro de los cuadros para luego pasar de nuevo a la imaginación de los individuos que los contemplan cargadas ya del temor y temblor similares a los que pudo haber sufrido el santo.

La popularidad de las Tentaciones de San Antonio puede haber dependido de la actuación culta y de la medida en que se hayan ofrecido como modelos. Pero fundamentalmente tal popularidad reanimada regularmente en los rituales festivos ha dirigido sus ojos a la imagen del patrono cuyos 
motivos no parece que hayan bebido de las fuentes hagiográficas primeras. Son una serie bien definida y a pesar de todo el santo ha sido a menudo confundido con San Antonio de Padua. Los motivos son los siguientes:

Un monje viejo y barbudo.

Con hábito talar oscuro o negro, manto y capucha, a veces gorro negro que le cubre cabeza y orejas.

Báculo de abad o bastón que termina en T.

Letra Tau sobre el manto a la altura de los hombros (antonianos).

Libro abierto en una mano.

Campanilla que cuelga del bastón. (Según Grace Sill —1975 - para expulsar a los demonios).

Llama de fuego sobre la mano o sobre el libro o en el suelo.

Cerdo a los pies (a veces de éste cuelga también la campanilla: gorrino de San Antón).

El contraste con la "imagen" proporcionada por las hagiografías primeras y también con la que se enfrenta a las "tentaciones" es muy acusado. Aquí la imagen se ha construido mediante la adición de una serie de signos identificadores según el código expresivo que llegó a generalizarse para las imágenes de devoción en la línea de que éstas debían ser "Biblia pauperum", es decir, libros que supieran leer los pobres, aquí caracterizados como no letrados. Es destacable que estos signos de identificación transponen anacrónicamente la figura que ya no representa tanto al anacoreta egipcio de los primeros siglos de Cristianismo agitados por las herejías cuanto a un monje de monasterio y de calle en un periodo ya de asentamiento, en el que el clero regular jugaba un papel social relevante y en el que las órdenes religiosas competían por una mayor visibilidad social. Y sobre todo presenta y representa a un santo patrón. Uno de los que en la Baja Edad Media se llegaron a extender más allá de los asuntos humanos. (Mâle -1998 - cita entre otros a San Cornelio para los bueyes, San Gall para las gallinas, San Antonio para los cerdos, San Saturnino para las ovejas, San Medardo para que las viñas se libren de la helada).

Y en la medida en que se labra así la imagen de un santo patrón, los signos pueden haber sido integrados para reconocimiento particularizado de sus fieles devotos asignados a su amparo. Estos signos revelan una apropiación por parte de la orden religiosa que adoptó su patronazgo y acometió la difusión de su devoción: los antonianos. Se ha convertido pues en una imagen de esos monjes y de los devotos cuerpos sociales bajo su protección.

La imagen de los antonianos se reconoce por los signos del monacato, rostro venerable, hábito talar, reforzados por el báculo de abad (terminado en T) y por la letra Tau sobre el manto. El significado de la letra Tau ha sido objeto de especulación. Según Grace Sill es la inicial de Theos. Aun- 
que más bien es una reelaboración de la "crux ansata" o egipcia, tal vez adoptada por monjes anacoretas (D’Alviella 1956). Y los sujetos -y objetos- de patronazgo están bien explícitos por medio del cerdo y la llama de fuego. No obstante, un listado de los patronazgos de San Antón según los libros piadosos modernos se ofrece para un amplio espectro de personas y animales. Como recuerda Wirth (1989), San Antón forma parte de la panoplia de santos especialistas cuyo culto fue fomentado, a la vez que se fijaba el amor a las imágenes (siglos XIV y XV), después de algunas dudas iconoclastas anteriores. Se forjaron imágenes realistas acompañadas de signos identificatorios claros. Las especializaciones están recogidas en una serie de patronazgos: de animales, enfermos de gangrena, amputados, cesteros, fabricantes de cepillos, enterradores, ermitaños, monjes, porquerizos, afectados de eczema, de ergotismo, erisipela y enfermedades de la piel. Las justificaciones son variadas y están a veces basadas más o menos fundadamente en algunos aspectos de la hagiografía primera, o reelaborada. Se dice que es patrono de los cesteros porque en su tiempo de eremita se dedicaba a hacer cestas como descanso en las prácticas ascéticas, patrono de enterradores por haberse encargado de enterrar a otros eremitas y en concreto a San Pablo, etc.

El patronazgo sobre los cerdos en particular parece previo al luego generalizado a todos los animales. Y su justificación es peculiarmente confusa. El caso es que presumiblemente se encuentra más relacionado con el otro signo, el de la llama de fuego, de lo que se cree. Es una discusión con matices variados, alguno de los cuales apunta a cuestiones teóricas de cierto rango.

Un primer aspecto es la identificación precisa del animal. Sebastián (1994) supone que más bien es lechón y que San Antón es quien defiende a las crías de cerdo. Más comúnmente se tiene como simple cerdo sin mayor especificación y si bien se ha subrayado también que es patrono que vela por que a los cerdos no les afecte la roséola, la generalidad liga su presencia dentro del conjunto iconográfico a la dedicación hospitalaria de la Orden de los antonianos. A menudo a ese cerdo se le hace equivaler al llamado "gorrino de San Antón", una práctica ritual muy difundida en poblaciones rurales en España y que procuraba cada año un cerdo para ser criado y mantenido por la comunidad y luego ser subastado o rifado el día de la fiesta del santo. Tal cerdo iba con una campanilla al cuello alertando a los vecinos de su presencia y de la obligación de acogerle y mantenerle mientras estuviera dentro del espacio doméstico de cada cual. La asociación de los cerdos con la Orden de antonianos, dedicada al cuidado de enfermos y peregrinos, está documentada en muy distintas partes de Europa. La sede principal de esa Orden estuvo en San Antonio de Vienne (Francia), desde 
donde se expande a España, Italia, Germania, Portugal. Y luego al Nuevo Mundo. Entre 1131 y 1190 se desarrolla desde el departamento de Isere hacia el Drôme en los Alpes con la abadía de Bourg-St. Antoine. De 1190 data su presencia en Roma, luego en Memnigen, Montferrand, Aumonnieres, Besançon, Grandvaux. Y en Castrojeriz y luego en Olite. Después en Versucchien, Frankfort, Maastricht y Albi, en Francia. Entre 1270 y 1280 se fundan bastantes monasterios: Marsella, Aviñón, Lyon, Montbrisson, Marsans, Granduaux, etc. En Alemania: Lichteburg, Grünberg, Estrasburgo, Alzey, Kleve, Friburgo, etc. En Italia: Módena. Milán, Rauverso, Génova, Venecia, Perugia, etc. Además de hospitales centrales se erigían capillas para atender a los necesitados como en Volterra, Kleve, Maastricht, etc. Luego en Poavia, en Bannes, en Veynes, en Fabriano, en Burgo Sto. Donino, etc., todo en el primer cuarto del siglo XIV. En el siglo XV en Alejandría, Brescia, ... Con la aprobación de los estatutos en 1477 se contaron 192 preceptorías generales y subalternas. Aunque ciertamente muchas preceptorías y fundaciones fueron efímeras por diversos motivos, no debe pasar desapercibida la velocidad y amplitud de desarrollo de la Orden por toda Europa (Sánchez Domingo 2004).

En España, la Orden contaba con varios monasterios. El de Castrojeriz data de 1146 y debe tenerse como fundación hospitalaria en el Camino de Santiago. En Cervera en 1215, en Lérida 1271, en Valls a fines del XIII, en Tárrega 1315, en Perpiñán 1319, en Barcelona 1434, en Mallorca antes de 1250 y luego en Segovia, Toledo, Madrid. En el siglo XVI está organizada en dos preceptorías generales, la de Castrojeriz y la de Olite, con jurisdicción en Castilla, Andalucía, Portugal, Granada e Indias Orientales, la una, y la otra, sobre Navarra, Aragón, Valencia, Baleares, Cataluña, Rosellón y Cerdaña con casas en Perpiñán, Cervera, Barcelona, Lérida, Zaragoza, Valencia, Calatayud, Vallés, Pamplona, Tárrega, Tudela y Mallorca.

Encomiendas, monasterios y hospitales en: Albacete, Alfaro, Atienza, Barcelona, Benavente, Cadalso, Calatayud, Cervera y Valls, Ciudad Real, Córdoba, Cuenca, Lérida, Madrid, Mallorca, Medina del Campo, Murcia, Pamplona, Perpiñán, Remolinos, Salamanca, Segovia, Sevilla, Talavera, Tárrega, Toledo, Toro, Tudela, Valencia, Valladolid, Zaragoza. Hay constancia de su presencia en otros lugares: Alcázar de San Juan, Alfaro, Arcos de Porral, Ascó, Borjas Blancas, Camarasa, Cambrils, Castelló de Farfaña, la Matarraña, la Conca del Barberá, Consuegra, Falset, Fortaleny, Igualada, Jaén, Llanes, Malgrat, Milagro, Pastrana, Parrés, Pereña, El Priorato, Ribera del Ebro, Tafalla, Torre del Español, Vich, Vilaseca, Villarrubia de los Ojos, Vilanova y la Geltrú, Valsarem.

Los monjes que recorrían las zonas de influencia recogiendo limosnas eran llamados bacinatores y se les otorgaron privilegios reales. Alguno de ellos hace referencia explícita a la cría de cerdos. Hay documentación rela- 
tiva a privilegios concedidos a la encomienda de Castrojeriz por Enrique IV en 1304 y luego por los Reyes Católicos. La Orden fue suprimida en 1787 por Pío VI y anteriormente ya había sido objeto de expropiación por Carlos III (Sánchez Domingo 2004; Palacín 2002).

Había ordenanzas de policía que prohibían que hubiera cerdos sueltos por las calles, a excepción de los antonianos que ponían campanas a los que pertenecían a sus hospitales para conseguir alimentos para ellos. Este privilegio es el que se conmemoraba por medio de grabados, tal vez sellos, que mostraban al santo con un cerdo con campanilla. Una imagen que pervivió aunque el significado original se perdió. Hay una prueba de ello en la T que invariablemente se ponía en el hábito del santo. Era el blasón de la Orden y recordaba a los monjes su dedicación a los enfermos. El cerdo persistió en las obras del XV y XVI cuando la memoria de la antigua Orden hospitalaria ya se había perdido.

Uno se admira, dice Mâle (1898) como ejemplo de una mala interpretación tal vez inducida por otras asociaciones como la de San Jorge y el dragón, de cómo a fines del xIV San Antonio va siempre acompañado de un cerdo que lleva una campana. La gente pensaba que el santo vivía en el desierto acompañado de este fiel animal, pero nada de eso se lee en la historia eremítica. Debió ser por confusión con una imagen de la fraternidad de monjes antonianos.

Otras justificaciones se hicieron corrientes en las hagiografías barrocas del santo. Se cuenta en las tradiciones catalanas que obró un milagro con un cerdo ciego y tullido, aunque otras versiones indican que era un jabalí hembra,... Milagro que hizo el santo en vida, también en el curso de un viaje milagroso que realizó a tierras del Conde de Barcelona, habiendo sido llamado por éste (Navarro 2002 [1683]; Ceballos 1994 [1759]).

Y como muestra de sobre-interpretaciones se ha llegado a decir que el cerdo no es más que un símbolo de la lujuria vencida por el santo en su vida en el desierto (Grace Sill 1975). O no tan concretamente ligado a las pasiones, como símbolo de los demonios con los que enfrentó.

Es tal la ambigüedad de la presencia del cerdo en el conjunto iconográfico de San Antón que tanto se sugiere que es objeto de la protección del santo como memoria de sus tentaciones o, aún más, de los demonios que le asediaron durante su estancia en el desierto, y tanto objeto de sus milagros como fuente de recursos de los monjes de la Orden antoniana.

Hasta Burke (1978) ha propuesto una teoría sobre ello: se cree que a San Antón se le acompaña de un cerdo porque su festividad coincide con la temporada de matanza. Lo destacable es que Burke lo aduce como ejemplo de que los rituales determinan los mitos.

Y más adelante comenta de qué modo la reforma católica encontró in- 
dignas algunas imágenes y cita el caso de un obispo de la diócesis de Orleans en 1682 que en la visita pastoral encuentra en un pueblo la imagen de San Antonio con un cerdo y la manda ocultar por considerarla indigna y ridícula, aunque sus feligreses no deseaban perderla y comentaron que el obispo descendía de la raza de los hugonotes.

Además, el cerdo a los pies del santo recuerda a los devotos la práctica ritual del "gorrino de San Antón" que culmina el día de su fiesta.

La llama de fuego, por otro lado, recibe una casi unánime interpretación: remite al "fuego de San Antón". Hubo numerosas epidemias del siglo IX al XIV especialmente en las regiones orientales de Francia, Rusia y Alemania de consecuencias temibles para los afectados que "atormentados por atroces dolores lloraban en los templos y plazas, la enfermedad les corroía los pies o las manos y a veces la cara". Comenzaba con escalofríos, luego una quemazón y las extremidades se iban tornando negras, arrugadas y acababan por desprenderse. Mutilados y deformados, los enfermos sobrevivían. Aunque a menudo afectaba a las vísceras abdominales y en breve sobrevenía la muerte. Se llamó a estas enfermedades con un antiguo nombre, el de "fuego sagrado". Parece haber referencias al fuego sagrado en el 600 a. de C., entre los asirios. Y está citado por Plinio. Otros nombres han sido "mal de los ardientes", "fuego infernal". El de "fuego de San Antonio" data del siglo XI con la fundación de los monasterios de antonianos que acometieron la atención a sus víctimas. Hay constancia de que a fines del XVI los enfermos peregrinaban al santuario francés y recibían los cuidados de los monjes que llevaban en el hábito una $\mathrm{T}$ azul sobre el hombro. Tal vez la $\mathrm{T}$ simbolizaba las muletas. El hospital de Viennes en el XVII tenía una colección de miembros unos blanqueados y otros ennegrecidos, recuerdos de los enfermos.

Muy probablemente tras estas denominaciones se englobaron varias enfermedades cuya etiología y tratamiento ha diferenciado después la Medicina. Una de ellas puede haber sido la intoxicación por ingestión del cornezuelo de centeno, ergotismo. Intoxicación a la que se arriesgaban las poblaciones en las que el pan de centeno era habitual en la alimentación. Los manuales de Dermatología indican que hacia 1597 se descubre en Marburgo el hongo Claviceps purpúrea en la harina de centeno, desarrollado sobre todo en los años húmedos en las espigas del cereal suplantando a un grano y de color negro violáceo. El cornezuelo, se indica, tiene entre otras propiedades la de provocar la contracción de fibras musculares lisas (útero, vasos sanguíneos)... El alcaloide principal es la ergotamina, paralizante periférico del simpático. La intoxicación puede llegar a ser aguda, mortal. Y en dosis pequeñas pero repetidas se hace crónica con los síntomas ya descritos. Su relación con abortos ya era conocida de antiguo 
por comadronas y en el siglo XVIII se descubrieron sus efectos sobre las contracciones del útero.

Luego se denominó "fuego de San Antonio" al herpes zoster, una afección de origen vírico que hiere a las células nerviosas y se manifiesta en erupciones cutáneas similares a la varicela, etc., y provoca intenso picor. También ha podido ser confundido con la erisipela. En muchas localidades gallegas se denomina "fogardente" a los granos que salen a la cara y luego cunden y van cavando, forman costras grandes que caen una vez que cortan quedando manchas de color morado. Según Lis Quibén (1949) puede tratarse del Eczema postuloso.

La atención y el cuidado que los monjes prestaron a los afectados de estas enfermedades incluía por supuesto el ponerles bajo la protección del santo, pero además la aplicación de untos con manteca de cerdo. Ha sido recogida entre las tradiciones populares de los tratamientos de las enfermedades de la piel por Lis Quibén y por otros la utilización de untos elaborados ya con lechón blanco, con cerdo macho adulto desalado, etc. Siempre dentro de rituales terapéuticos de ejecución normalizada. P.e.:

En Laza atribuyen el mal de fuego a ropa secada al sol por la que haya pasado algún animal. Comienza con erupción en la espalda que luego se extiende y cierra por el pecho y entonces ya no tiene salvación. Se cura con un trozo de acero y pedernal haciendo saltar chispas dirigidas a la erupción y se recita un ensalmo. El paciente no debe pronunciar palabra mientras se hace esa operación nueve veces al día nueve días seguidos [...] En Golada se llama así a heridas en la cara que revientan y se curan con tierra de nueve toperas no holladas por gallinas mezcladas en un trapo y un poco de unto de lechón blanco y a la señal de la cruz, metido el unto en la tierra hacen con todo cruces sobre la cara del enfermo mientras citan el ensalmo: "Fogo ardente que queimas a la gente" [...] Tres veces seguidas el mismo día y tres días seguidos aunque el unto hay que cambiarlo cada día y el que se utiliza se mete en un agujero en la pared (Lis Quibén 1949).

Posiblemente el cuidado de los cerdos y los privilegios concedidos para ello a la orden antoniana hayan de ser justificados por poder disponer de materia prima para la elaboración de los untos.

El fuego no sólo es tomado metafóricamente para designar enfermedades aliviadas por intervención del santo sino que como elemento de la iconografía de éste se asocia al ritual festivo, pues en numerosas poblaciones la celebración tiene entre sus actos más relevantes las hogueras de los devotos. Y si con el cerdo las explicaciones de su presencia se desplazan de lo literal a lo metafórico, con el fuego oscilan en forma similar de lo metafórico a lo literal. Y en ambos casos siendo elementos de significación bien lejanos a la biografía de Antonio, el eremita del desierto, pero definitivamente integrados en la imagen con la que se le reconoce y venera. 
San Antón es una de las muestras más esclarecedoras, no tanto como se comentaba anteriormente de cómo los mitos suceden a los rituales, sino de cómo las poblaciones construyen, elaboran, fabrican las imágenes sagradas como representaciones de sí mismas, de sus capacidades y de sus debilidades, de sus sufrimientos y de sus esperanzas.

MATERIALES PARA UN ESTUdiO DIACRÓNICO DEL CULTO A SAN ANTÓN EN ESPAÑA

Se exponen a continuación algunos datos pertinentes extraídos de fuentes diversas que subrayan la extensión del culto a San Antón sin pretensión de hacer una historia de él sino de mostrar su arraigo. En las Relaciones topográficas pueden hallarse algunos datos bien significativos del culto en el siglo XVI.

TABLA 1

Ermitas y votos a los santos en algunas poblaciones españolas en el siglo $X V I$

\begin{tabular}{lcc}
\hline \multicolumn{1}{c}{ Advocaciones } & Ermitas & Votos \\
\hline - Virgen María & 286 & 126 \\
- Sebastián & 165 & 213 \\
- Magdalena & 31 & 13 \\
- Ana & 29 & 73 \\
- Roque & 28 & 60 \\
- Bartolomé & 27 & 6 \\
- Juan Evangelista & 26 & 26 \\
- Santiago & 23 & 4 \\
- Cristóbal & 22 & 1 \\
- Pedro & 20 & 14 \\
- Antonio Abad & 19 & 46 \\
\hline
\end{tabular}

(FuENTE: Relaciones Topográficas de Felipe II. Ver W. Christian 1981).

Por el número de ermitas puede apreciarse ya su importancia, pues la dedicación de una ermita significaba un nivel alto de relevancia en la religiosidad. Pero debía haber muchas parroquias o ermitas con otras dedicaciones que contuvieran ya entonces imágenes del santo (ver Tabla 2), y muchas las han mantenido a lo largo del tiempo o las han renovado.

El número de votos guardados - y por tanto de fiestas celebradas- indica que el culto estaba en un nivel bastante más alto en el ranking de las devociones que lo que dice el de ermitas. El voto era entre las prácticas de 
devoción aquella que expresaba mejor una vinculación duradera entre las poblaciones y los santos.

Algunas explicaciones de voto eran:

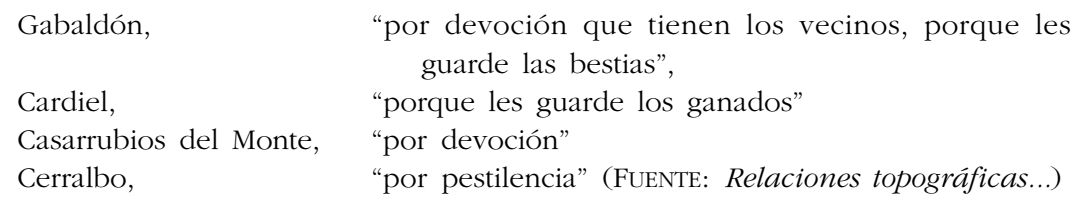

Estas fórmulas (como las otras) se debían tener como acostumbradas de modo que se daba por sentado que la devoción a San Antón era la correspondiente actitud a una demanda específica: "porque les guarde las bestias", anotó el escribano. Se refiere a las bestias de labor y a los ganados en general y la demanda debe haber sido en ocasiones urgente y con la carga de ansiedad y preocupación que en poblaciones campesinas tiene la salud y el vigor de los animales de los que depende su supervivencia, pero sobre todo y por lo mismo se trataba de una demanda regular ritualmente renovada con ocasión de la fiesta.

TABLA 2

Parroquias y ermitas en Navarra con imágenes de San Antonio Abad (siglos XVI-XVII) y los talleres de procedencia

\begin{tabular}{ll}
\hline Taller de Pamplona & Taller de Sangüesa-Lumbier \\
\hline Ochagavía & Alzórriz \\
Imárcoain & Liédana \\
Biurrun & Artieda \\
Muruarte de Reta & Abaurrea Baja \\
Ardanaz & Garayoa \\
& Esparza de Salazar \\
& Grez \\
& Elorz \\
& Tabar (colateral) \\
& Ituren \\
Taller de Estella & \\
Learza & \\
\hline
\end{tabular}

(FuENTE: García Gainza 1986)

La devoción ha persistido a lo largo del tiempo sin haberse modificado sustancialmente el rango. El papel de santo especialista puede ser lo suficientemente explicativo de ello. En la jerarquía de las devociones ésta no 
parece haber sufrido grandes modificaciones hasta la época de la implantación generalizada de la maquinaria agrícola. Los siguientes datos recogidos de fuentes diversas son muestra de la existencia del culto en algunas poblaciones del centro de la Península.

TABLA 3

Poblaciones con culto a San Antón (siglos XIII-XX)

\begin{tabular}{|c|c|c|c|}
\hline Provincia de Madrid & parroquias & capillas & ermitas \\
\hline - Aldea del Fresno & & & 1 \\
\hline - Algete & 1 & & \\
\hline - Cadalso de los Vidrios & & 1 & \\
\hline - Cenicientos & & & 1 \\
\hline - Ciempozuelos & & & 1 \\
\hline — Chinchón & & & 1 \\
\hline - Hoyo de Manzanares & & & 1 \\
\hline - Pinto & & & 1 \\
\hline — Torrejón de la Calzada & & & 1 \\
\hline — Valdemoro & & & 1 \\
\hline - Vallecas & & & 1 \\
\hline — Villanueva del Pardillo & & & 1 \\
\hline \multicolumn{4}{|l|}{ Provincia de Toledo } \\
\hline - Ajofrín & & 1 & \\
\hline - Almonacid & 1 & & \\
\hline - Añover de Tajo & & & 1 \\
\hline — Casarrubios & & & 1 \\
\hline - Dosbarrios & & & 1 \\
\hline - Horcajo & & 1 & \\
\hline — Lillo & & & 1 \\
\hline - Quintanar de la Orden & & & 1 \\
\hline - Santa Cruz de la Zarza & & & 1 \\
\hline - Talavera & & & 1 \\
\hline - Tembleque & & & 1 \\
\hline - Urda & & & 1 \\
\hline - Villafranca de los Caballeros & & & 1 \\
\hline
\end{tabular}

(FuENTE: elaboración de Roberto Fernández sobre datos de las Relaciones del Cardenal Lorenzana y el Diccionario de Madoz).

La focalización entre San Antón o San Antonio de Padua, introducida la devoción a éste mucho más tarde, puede verse en la tabla siguiente (según datos proporcionados por W. Christian y para el Valle del Nansa hacia 1969). 
TABLA 4

Imágenes de Cristo, la Virgen y los santos en iglesias y capillas del Valle del Nansa

$\begin{array}{lr}\text { Sagrado Corazón de Jesús } & 17 \\ \text { Inmaculada Concepción } & 11 \\ \text { San José } & 11 \\ \text { San Antonio de Padua } & 10 \\ \text { Ntra. Sra. Carmen } & 7 \\ \text { Ntra. Sra. Rosario } & 6 \\ \text { Ntra. Sra. Fátima } & 6 \\ \text { San Roque } & 6 \\ \text { Cristo Crucificado } & 6 \\ \text { Inmaculado Corazón María } & 5 \\ \text { San Miguel } & 4 \\ \text { San Antonio Abad } & 3 \\ \text { Niño Jesús de Praga } & 3\end{array}$

(FuEnTE: W. Christian 1978).

En este caso más que en otros la fiesta es el acto más destacado de la devoción pues no parecen haberse desarrollado tanto formas privadas, particulares de individuos o familias que conllevan oraciones y peticiones que se quedan en los ámbitos de la intimidad, sino sobre todo formas colectivas, comunitarias, de expresar las vinculaciones con un santo que en algún momento dejó de ser el auxilio y consuelo de los afectados del fuego de San Antón para pasar a ser más que otra cosa el abogado y protector de los animales y ganados. Tampoco es posible ofrecer datos generales de su celebración en distintos tiempos pero sí alguna muestra con la que subrayar cuan común ha llegado a ser.

El mapa elaborado por A. Rivas (1986) sobre datos de poblaciones de la provincia de Zaragoza pone de manifiesto que la fiesta de San Antón se celebraba en muchísimas poblaciones y no necesariamente como fiesta de guardar sino manteniendo determinadas prácticas que congregan a las gentes y les hacen coincidir en las preocupaciones y en los gozos. 


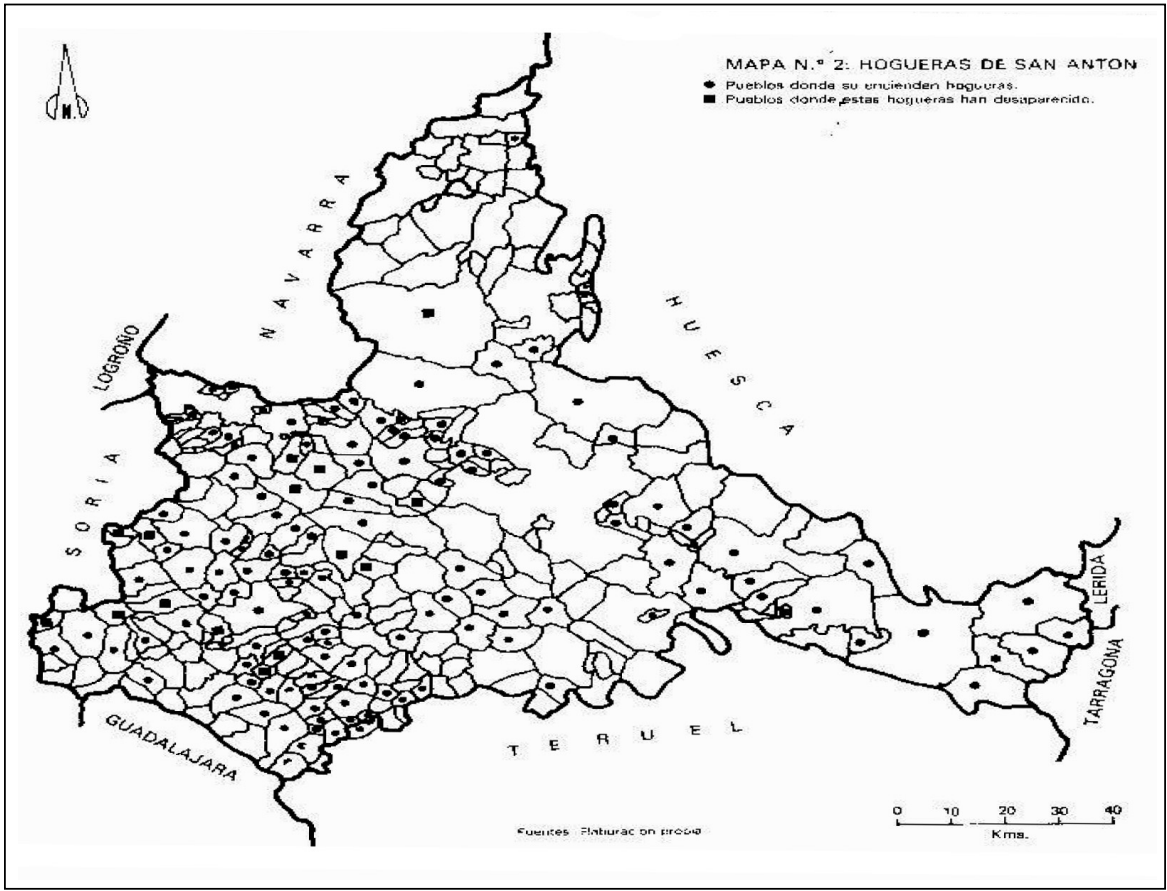

MAPA 1

FORMAS FESTIVAS EN LAS CELEBRACIONES DE SAN ANTÓN EN ESPAÑA Y OTROS LUGARES

No es posible dar una relación completa de las poblaciones españolas que celebran la fiesta. Aún faltan guías etnográficas de muchas áreas y regiones. Sí puede sin embargo ofrecerse una buena muestra con los datos disponibles advirtiendo que se trata de poblaciones en las que se celebra en la actualidad a San Antón. En general esto comporta una continuidad a lo largo de un tiempo, tal vez varios centenares de años, en otras se hablaría más bien de celebraciones interrumpidas y luego reestablecidas. Muy pocas veces se trata de celebraciones de nuevo cuño, aunque algunas fiestas mayores incluyen en sus programas actos que se tienen como "novedades" o se han producido modificaciones respecto a las prácticas consideradas "tradicionales". La tabla siguiente es un listado amplio de poblaciones: 
TABLA 5

Las formas festivas por San Antón

\begin{tabular}{|c|c|c|c|c|c|c|c|c|}
\hline & Hogueras & Danzas & Demonio & \begin{tabular}{|l|} 
Bendic. \\
animales \\
\end{tabular} & $\begin{array}{l}\text { Sorteo } \\
\text { cerdo }\end{array}$ & $\begin{array}{l}\text { Romería } \\
\text { Procesión }\end{array}$ & Comida & $\begin{array}{l}\text { Juegos } \\
\text { Mercado, etc }\end{array}$ \\
\hline ALGAIDA & foguerons & Els Cossiers & + & & & & & \\
\hline ALICANTE & & & & & + & & & porrate \\
\hline ALMAGRO & + & & & & Subasta & & & \\
\hline ALOSNO & $\begin{array}{l}\text { Luminarias } \\
\text { Saltos }\end{array}$ & & & & & & & \\
\hline ARONA & & & & & & + & & + \\
\hline ARQUILLOS & & & Pelotero & (voto) & & + & & \\
\hline ARTÁ & + & & Dos & & & cabalgata & Espina-gades & Glosa-dors \\
\hline BÉJAR & & & & + & & & Mantelada & \\
\hline BENICASSIM & + & $\begin{array}{l}\text { Del } \\
\text { Cremaller }\end{array}$ & & & & & Coqueta & $\begin{array}{l}\text { Toro } \\
\text { embolao }\end{array}$ \\
\hline BIHAR & & & $\begin{array}{l}\text { Rei } \\
\text { Paixaro }\end{array}$ & + & $\begin{array}{l}\text { Subasta } \\
\text { de panes } \\
\text { típicos }\end{array}$ & $\begin{array}{l}\text { De } \\
\text { antorchas } \\
\text { Cavallá }\end{array}$ & & \\
\hline BROZAS & & $\begin{array}{l}\text { Torcer el } \\
\text { cordón }\end{array}$ & & & & Carrozas & panes típicos & \\
\hline $\begin{array}{l}\text { CALDES DE } \\
\text { MONTBUI }\end{array}$ & $\begin{array}{l}\text { Un cirio al } \\
\text { santo }\end{array}$ & $\begin{array}{l}\text { De S. } \\
\text { Antoni }\end{array}$ & & + & & cabalgata & panecillos & \\
\hline CANALS & + & & & & & $\begin{array}{l}\text { Procesión } \\
\text { Els parells }\end{array}$ & embotits & carreras \\
\hline CAPDEPERA & + & & + & + & & + & & \\
\hline $\begin{array}{l}\text { CIUDAD } \\
\text { RODRIGO }\end{array}$ & & & & & $\begin{array}{l}\text { Subasta } \\
\text { de } \\
\text { chacina }\end{array}$ & & Panecillos & \\
\hline CIUTADELLA & & & & & & Tres Tocs & $\begin{array}{l}\text { Naranjas, } \\
\text { dátiles. }\end{array}$ & mercado \\
\hline ELCHE & & + & & + & + & + & & porrat \\
\hline ESTERCUEL & + & & & & $\begin{array}{l}\text { Subasta } \\
\text { ofrendas }\end{array}$ & $\begin{array}{l}\text { Encamisa- } \\
\text { da }\end{array}$ & $\begin{array}{l}\text { Chorizo } \\
\text { Pan bendito }\end{array}$ & \\
\hline FALSET & & & + & + & & $\begin{array}{l}\text { Encamisa- } \\
\text { da }\end{array}$ & panecillos & \\
\hline $\begin{array}{l}\text { FORCALL } \\
\text { Santantoná }\end{array}$ & $\begin{array}{l}\text { Barraca } \\
\text { Hoguera } \\
\text { Saltos }\end{array}$ & $\begin{array}{l}\text { Sants } \\
\text { Despullat } \\
\text { Cremaller } \\
\text { Filoseta }\end{array}$ & + & + & & caballerías & & \\
\hline GUADIX & Luminaria & & & $\begin{array}{l}\text { Nueve } \\
\text { vueltas }\end{array}$ & & + & cucaña & \\
\hline HUÉSCAR & $\begin{array}{l}\text { Castillos de } \\
\text { tea }\end{array}$ & & & & & + & cuerva & \\
\hline JAÉN & Lumbres & Melenchón & & & & & $\begin{array}{l}\text { Calabazas } \\
\text { Maíz }\end{array}$ & coplas \\
\hline LA ALBERCA & & & & & + & & & \\
\hline LA TODOLELLA & $\begin{array}{l}\text { Santantonà } \\
\text { Barraca }\end{array}$ & & Diablera & & & & & \\
\hline $\begin{array}{l}\text { LUCENA DEL } \\
\text { CID }\end{array}$ & $\begin{array}{l}+ \\
\text { Saltos } \\
\end{array}$ & & & & & $\begin{array}{l}\text { Machá } \\
\text { cabalgata }\end{array}$ & $\begin{array}{l}\text { Torta de } \\
\text { aceite }\end{array}$ & \\
\hline MADRID & & & & + & & + & panecillos & \\
\hline MANACOR & + & $\begin{array}{l}+ \\
\text { cantores }\end{array}$ & + & & & & & \\
\hline MANLLEU & & Del ciri & & & & $\begin{array}{l}\text { Desfile } \\
\text { caballerías } \\
\text { y carrozas }\end{array}$ & & \\
\hline MENGÍBAR & luminarias & & & + & & + & $\begin{array}{l}\text { Chorizo } \\
\text { Maíz }\end{array}$ & coplas \\
\hline MIRAMBEL & Barraca & & + & & & & & \\
\hline
\end{tabular}




\begin{tabular}{|c|c|c|c|c|c|c|c|c|}
\hline MOCLÍN & & & & & \begin{tabular}{|l|} 
Se mata \\
para \\
todos \\
\end{tabular} & + & & \\
\hline MORCÍN & & & & & & & \begin{tabular}{|l|} 
Nabos \\
Casadielles
\end{tabular} & \\
\hline MOREDA ALLER & & & & & \begin{tabular}{|l|} 
Puya del \\
ramu y \\
lacones
\end{tabular} & & casadielles & \\
\hline MORELLA & Barraca & $\begin{array}{l}\text { Vida del } \\
\text { sant, baile } \\
\text { de } \\
\text { personajes }\end{array}$ & + & & & + & panoli & \\
\hline $\begin{array}{l}\text { NAVALVI-LLAR } \\
\text { DE PELA }\end{array}$ & + & & & + & & $\begin{array}{l}\begin{array}{l}\text { Encamisá } \\
\text { carrera }\end{array} \\
\end{array}$ & biñuelo & \\
\hline NOGUE-RUELAS & & & & + & \begin{tabular}{|l|} 
Subasta \\
de \\
ofrendas \\
Rifa de \\
cerdo
\end{tabular} & & & \\
\hline OBEJO & & $\begin{array}{l}+ \\
\text { de } S . \\
\text { Benito }\end{array}$ & & & & + & & \\
\hline ORCE & & \begin{tabular}{|l} 
Soldadesca \\
Tentaciones \\
del santo \\
\end{tabular} & $\begin{array}{l}\text { Cascamo- } \\
\text { rras }\end{array}$ & & & & & $\begin{array}{l}\text { Juego de } \\
\text { bandera }\end{array}$ \\
\hline PALMA M. & & & & + & & Cabalgata & & \\
\hline PETRA & + & & & + & & carrozas & & coplas \\
\hline PINTO & & & & + & & & & $\begin{array}{l}\begin{array}{l}\text { Suelta de } \\
\text { naranjas }\end{array} \\
\end{array}$ \\
\hline POLLENSA & + & & & + & & cabalgata & & $\begin{array}{l}\text { Coloc. Y } \\
\text { subida al } \\
\text { pino }\end{array}$ \\
\hline $\begin{array}{l}\text { PUERTO } \\
\text { MINGALVO }\end{array}$ & + & & & + & & $\begin{array}{l}\text { Corrida de } \\
\text { machos }\end{array}$ & caridad & \\
\hline PUIG REIG & & & & + & & $\begin{array}{l}\text { Corrida } \\
\text { Carrozas y } \\
\text { caballer. }\end{array}$ & $\begin{array}{l}\text { Matanza del } \\
\text { cerdo }\end{array}$ & \\
\hline $\begin{array}{l}\text { RUBIELOS DE } \\
\text { MORA }\end{array}$ & + & & & + & tranceo & + & molletes & \\
\hline SA POBLA & + & & + & & & & & Coplas \\
\hline $\begin{array}{l}\text { SAN BARTO- } \\
\text { LOMÉ DE P. }\end{array}$ & $\begin{array}{l}+ \\
\\
\text { saltos }\end{array}$ & & & & & & & $\begin{array}{l}\text { Correr } \\
\text { cintas }\end{array}$ \\
\hline S. EUGENIA & + & & & + & & carrozas & \begin{tabular}{|l|} 
Pan \\
sobrasada \\
\end{tabular} & \\
\hline SINEU & + & De bot & & & & & & \\
\hline $\begin{array}{l}\text { TORREPERO- } \\
\text { GIL }\end{array}$ & + & & & & & & $\begin{array}{l}\text { Garbanzos } \\
\text { tostados, } \\
\text { ponche }\end{array}$ & \\
\hline $\begin{array}{l}\text { VALLS } \\
\text { Tres tombs }\end{array}$ & & & & & & $\begin{array}{l}\text { Carruajes } \\
\text { caballerías }\end{array}$ & & \\
\hline $\begin{array}{l}\text { VELILLA DE S. } \\
\text { ANTONIO }\end{array}$ & & & & + & $(+)$ & & cerdo & \\
\hline VERIN & + & & & & & & Chorizo & \\
\hline $\begin{array}{l}\text { VILANOVA } \\
\text { ALCOLEA }\end{array}$ & $\begin{array}{l}+ \\
\text { saltos } \\
\end{array}$ & & & & & \begin{tabular}{|l|} 
Caballos \\
enjaezados
\end{tabular} & coca & carrera \\
\hline XÁTIVA & + & & & + & & & & \\
\hline
\end{tabular}

(Elaboración propia con datos de diversas Guías de fiestas, algunas impresas y otras en www.) 
Algunos comentarios primeros:

- Ciertamente aparecen en el listado más poblaciones de ciertas áreas geográficas, p.e. Baleares, Levante, Aragón, Nordeste de Andalucía... Y menos de otras áreas del Norte o del Centro. No debe tomarse esta distribución como significativa. La difusión en todo caso alcanza más allá de los lugares en donde hubo hospital o casa vinculados a los antonianos.

- El listado en realidad pretende ilustrar sobre todo acerca de la variedad de las formas festivas que caracterizan la celebración.

- La (+) indica presencia de rasgo confirmada.

- En múltiples casos se hace constar el nombre que las propias poblaciones dan a la práctica mencionada. En otros se alude a ellas con una denominación general, p.e.: hogueras, danza, etc.

- Como se trata de un cuadro comparativo no se especifican los cambios habidos a lo largo del tiempo ni cuándo se han producido. Se refieren todos los datos aportados a la actualidad.

- El orden del listado es arbitrariamente alfabético. Cabría hacer agrupaciones por afinidades en las cuales no siempre el factor de proximidad es determinante, por ejemplo, Pollensa y Sa Pobla en Mallorca celebran al santo de modos destacadamente distintos.

Las formas festivas básicas en las sociedades modernas suelen aparecer reseñadas en los programas con una tendencia marcadamente uniforme. Los ingredientes fundamentales de las fiestas entonces se reducen a algún acto público y célebre (en el sentido conectado que tiene esta palabra con la 'celebración') civil o religioso, alguna actividad de comensalidad y alguna de diversión o juego. El remedo de este esquema en las sociedades tradicionales reduce el programa a misa, banquete y baile. Se diría que este esquema viene a reproducir en contrapunto las rutinas de la vida cotidiana, en buena medida compensando por dedicación del ocio las restricciones y austeridades que exige la vida del trabajo aunque también intensificando aquellos aspectos que sólo parcial y brevemente se usan para salir al menos por un instante de la implacable rueda de obligaciones sociales y laborales.

Frente a esa visión simplificadora, las formas festivas en las sociedades tradicionales aparecen más que otra cosa como numerosas y variadas. Las dimensiones de la variedad se fijan fundamentalmente en dos líneas:

Entre las poblaciones españolas con dedicaciones diferenciadas a los distintos cultivos y aprovechamientos de la tierra y enclavadas en distintos nichos ecológicos se podían apreciar en el pasado algunos rituales festivos comunes, no sólo los implantados por la Iglesia Romana, veladora de una 
cierta unidad litúrgica y dogmática entre los creyentes o por iniciativa de alguna de las Órdenes religiosas promotoras y difusoras de devociones a ciertos santos o advocaciones marianas o cristológicas (también acompañadas de ciertas prácticas devotas); también es posible hallar actividades festivas comunes en la cultura popular seguramente sujetas a modas y especialmente aquellas trasladadas de un lugar a otro por diversos grupos de feriantes que recorrieron la península y las islas y de las que hay constancia ya desde la Edad Media de su movilidad de pueblo en pueblo llevando representaciones teatrales, danzas, melodías, ritmos, vestimenta, etc., elementos que luego algunas poblaciones mantuvieron y reelaboraron apreciándolos como propios. Ésta es ya una importante fuente de variedad, pero sobre todo lo es aquella que se ha ido forjando a costa de integrar en las formas festivas elementos diferenciales del medio ambiente y de las actividades socioeconómicas de dedicación: Fiestas de trashumantes y pastores, fiestas marineras, fiestas de poblaciones de ribera, fiestas de carreteros, fiestas cerealistas, fiestas huertanas, fiestas de madereros, fiestas del vino, del olivo,... fiestas de los oficios, fiestas de comerciantes, etc.

Por otro lado, en una misma población o entre las poblaciones de un contorno - pues muchas veces hay que considerar que los ciclos rituales integran varias poblaciones que se movilizan de unos a otros lugares para asistir a celebraciones comunes - había una significativa variedad en las fiestas que componían el ciclo anual, que se atenía a las divisiones del año en estaciones, de modo que entre las fiestas de invierno y las de verano la variedad marcaba no sólo el paso del tiempo sino que pareciera como si se vivieran mundos distintos. Además muchas de las fiestas proporcionaban cierto protagonismo a algunos de los sectores de la sociedad, niños, jóvenes, mujeres, etc., pero también los oficios, las hermandades y cofradías, e incluso las instituciones, cuya manera de hacerse visibles socialmente encontraba fórmulas expresivas de distinción con especializaciones en el ámbito del ritual que en determinados casos se dirían casi profesionales.

Estas dos líneas de dimensiones de la variedad festiva son hoy contenidos nucleares del patrimonio cultural de los pueblos, y por eso mismo a la vez, valores de la creatividad popular y del acentuado sentido de la tradición, sin que ambas cosas se consideren contradictorias. Son por un lado expresión de identidades colectivas que reelaboran la variedad como mensaje auto-referencial y con resonancia en el exterior a veces intencionadamente buscada y, por otro lado, hitos en el tiempo que trasladan la idea de regularidad en el cambio.

Pero estas dos líneas apuntan a un sentido de la variedad que se cumple apropiadamente tan sólo dentro de un sistema de fiestas. A diferencia de la fiesta en la modernidad cuyo sentido se cierra en la sucesión ininte- 
rrumpida y regularizada del tiempo en dos estados (tiempos laborales y tiempos de ocio) la variedad de las formas festivas implica que el tiempo es variable y en cierto sentido inciertamente variable, de modo que los ritos festivos conforman un sistema del tiempo cuya sucesión regularizada se concibe relacionada si no dependiente de la celebración ritual. Las fiestas son a la vez marcas en el calendario o lo que es lo mismo, marcas del cambio de los tiempos y activadores efectivos de esos cambios. Es decir indican, como la Candelaria, que acaba el invierno o, como el Mayo, que llegó la primavera, o como San Juan, que se echó encima el verano, pero eso no es sólo un anuncio, es también una puerta abierta, una activación. El paso del tiempo, el cambio de los tiempos lo dan las fiestas.

Es así cómo determinadas formas festivas logran ser por un lado marcas en el paso del tiempo y activadores de ese paso, de ese cambio. Con ellas se refleja el paso de un tiempo estacional a otro y, en la medida en que la celebración es principal, mayor — una fiesta patronal—, asciende de escala el reflejo y se hace perceptible y reflexivo el paso de los años. San Antón marca también el paso del tiempo, el cambio de los tiempos.

Esta concepción por supuesto no agota el sentido de la fiesta que desborda las propias formas y adquiere toda densidad como los símbolos dominantes de los que hablaba V. Turner. La fiesta como hecho social total remite a todos los ámbitos de la vida social y en ella hay a la vez intensa interacción social, intercambio de bienes, consumo suntuoso, fe conmovida, exhibición de los poderes, etc., etc.

En los rituales de San Antón en España la variedad destacable de las formas festivas se muestran en: las hogueras, la bendición de los animales, las procesiones y cabalgatas, ciertas danzas, la figura del demonio en un papel festivo, el sorteo del cerdo, comidas específicas (algunas a base de cerdo, pero también panecillos y otras) y ciertos juegos (carreras, por ejemplo), ciertas coplas (a menudo de temas "picantes").

Sobre tales formas se hace necesario advertir que:

Tomadas de una en una no están exclusivamente presentes en las fiestas de San Antón. Las hogueras se hacen en distintas fechas a lo largo del año, las bendiciones se dirigen a los campos, a los frutos, etc., en distintas épocas, danzas y papeles rituales para figuras singulares son representaciones frecuentes,... y por supuesto, sorteos o subastas, comidas, juegos y coplas son actividades festivas habituales.

Estas formas festivas no debieran ser tomadas como partes necesarias de un conjunto y de hecho no suelen darse todas a la vez y las que se dan se combinan de modos distintos. No todas ellas están presentes en todos los casos. Y sin embargo una vez instaladas y sancionadas por la "tradición” parecen estar articuladas y volverse complementarias unas de otras. 
El programa entonces quedaría incompleto si alguna de ellas no pudiera celebrarse.

Se podría decir que algunas constituyen modelos diferentes, generalmente configurados en torno a una forma festiva en especial, p.e. la hoguera o la cabalgata, la bendición o la danza. La fiesta se llega a nombrar por ellas: "Las Luminarias", "La Encamisada", "La Caballá", "Els Tres Tombs", "El Cascamorras", "La bendición de los animales", etc. Pero la fiesta suena también por sí misma y en alguna población (Forcall) se denomina como tal: "La Santantoná".

No hay datos disponibles para una arqueología de las formas festivas ni tampoco para fijar los tiempos y modos de combinación de esas formas. Claramente algunas han sido de intervención religiosa. Y probablemente los ritos del fuego son más antiguos. Estos y todos han sido sin embargo objeto de justificación continuada. El uso ritual de los productos de la matanza del cerdo, por ejemplo, se justifica en San Antón como recurso alimenticio de temporada, al menos para aprovechar determinadas partes que se consumen frescas y para aquellas elaboraciones que no requieren demasiado tiempo de curación. San Antón, además, fija la fecha de esa temporada por medio del ritual de sorteo o subasta del "gorrino del santo" en aquellas poblaciones en las que previamente se ha cuidado de él de manera mancomunada. En algunos casos toman el "gorrino del santo" como un bien objeto de redistribución, es decir, tras haber sido aportado como ofrenda, aquellas familias que no han podido hacer matanza (tal vez porque no les llega el dinero ni para la compra de un lechón que criar) pueden de esa manera abastecerse de carne para las duras jornadas que luego han de venir. Es en su función redistributiva la última matanza de la temporada con la que la comunidad cierra el ciclo.

En muchas poblaciones no es ése precisamente el alimento ritual característico sino los panes bendecidos, práctica que no encuentra explicación con el mismo criterio. Estos panes se distribuyen entre los devotos y a veces también entre los animales que son llevados a bendecir e incluso entre los que quedan en los establos. Las virtudes atribuidas al pan bendecido se infieren del amplio campo de protección que se supone asumido por el santo. El reparto del pan extiende el manto de protección más allá del reino de lo humano e incluso más allá de donde ha llegado el propio rito de la bendición. El reparto del pan bendito tiene de hecho lugar en otras poblaciones en diversas fechas a lo largo del año, en algunas se llama "pan caridad" y contribuye (contribuía) a ampliar la comunidad al menos efímeramente y al amparo del ritual por medio de la comensalidad a la que se llama a pobres y menesterosos (González Casarrubios 1985). Este pan bendito sin embargo al compartirse con los animales "domésticos" se suele cargar 
de significado profiláctico o terapéutico. Para consuelo de utilitaristas se subraya a este propósito que este "pan bendito" se hacía de trigo — no de centeno- con lo que se aliviaba o si no se evitaba al menos el mal conocido como "fuego de San Antón".

Estas son explicaciones que remiten las formas festivas a los contextos sociales y económicos articulando a su vez algunas de ellas entre sí. No obstante bien parece que se exige la aplicación de una lógica por la cual la identidad del santo ha de proporcionar sentido a la configuración festiva. Ya se dijo que el "gorrino de San Antón" que ha llegado a adquirir "forma” iconográfica y aparece inexcusablemente a los pies del santo es, o bien la representación de los demonios a los que se enfrentó en el desierto, o bien la de aquel jabalí (que la leyenda asegura que era más bien hembra y más bien ciega y tullida) que curó el santo en aquel milagroso viaje que hizo a tierras catalanas. Y el pan bendito encuentra de otro modo su justificación en un acontecimiento de la hagiografía bien notable que ha sido repetidamente recordado también por la iconografía: el reparto del pan que el cuervo llevaba regularmente a San Pablo en el desierto y que compartió con San Antonio cuando éste le fue a visitar.

Es fácil reconocer en estas justificaciones a las racionalizaciones secundarias — tan operacionales en los sistemas de creencias-. Aquí aportan la ilustración de la especificidad, del valor singular otorgado a unas determinadas formas festivas. Aquí están reafirmando, en suma, su variedad.

\section{HOGUERAS Y BENDICIONES}

En la serie de formas festivas antes reseñadas sobresalen dos: las hogueras y las bendiciones, como las más comunes, hasta el punto de que en numerosas poblaciones con ellas se compone el programa básico de las fiestas de San Antón. El interés que tiene centrar el estudio en ellas no sólo recoge esta circunstancia sino que posiblemente sean una buena fuente de sugerencias para profundizar en el análisis de los rituales.

Sobre el fuego ceremonial los clásicos de la Antropología proporcionaron una abundante información etnográfica. Uno de ellos, Frazer, hizo un pequeño tratado incluido en su La rama dorada. Tras una minuciosa exposición de datos referidos a los pueblos europeos en un intento de tipificación subraya primero la existencia de fuegos de regocijo en ciertos días del año para bailar y saltar por encima. Alude a los sínodos cristianos del siglo VIII en los que se habla de ellos entre las disposiciones para abolir los ritos paganos. Se hacían fundamentalmente en primavera y en otoño. Y no era infrecuente que se fingiera quemar efigies o personas vivas. Se preguntaba Frazer si no se trataba de huellas de sacrificios humanos. Clasificó los fuegos 
rituales por el calendario en fuegos cuaresmales, fuegos pascuales -inserta aquí los fuegos de Beltane el 1 de mayo-, fuegos del solsticio de verano, fuegos de Todos los Santos y fuegos del solsticio invernal. (Fuera de calendario habla además de los fuegos de auxilio).

Con este recuento etnográfico queda marcada la fijación temporal del fuego ceremonial y la gran dispersión a lo largo y ancho de Europa y en un arco temporal muy amplio de de una serie de prácticas cuyos aspectos formales y cuyas funciones e intenciones manifiestas resultan reconocibles. Así mostradas, fuera relativamente de sus contextos respectivos, parece un muy viejo conjunto de recursos festivos que fundamentalmente las poblaciones campesinas de Europa han activado y reelaborado a su modo. Esto seguramente incluye el reconocimiento de que deben ser prácticas muy antiguas.

En la misma línea, aportaciones etnográficas sobre Italia más recientes insisten en estos viejos planteamientos. La fiesta de la Candelaria cierra el invierno con luces y purificación. Se recuerda que el festival de Imbo a principios de febrero era una fiesta de luces para la diosa Brigitte la de la corona luminosa convertida en Brígida. Y Beltane era la fiesta que la seguía haciendo pasar al ganado entre hogueras humeantes. Para prevenir enfermedades e influjos nocivos. Los fuegos parecen ayudar al débil sol de invierno con sus luces y calores expulsando al frío, a las tinieblas y a las enfermedades. En muchas poblaciones rurales italianas San Antonio es a la vez protector de animales y titular de grandes fogatas. En Volgono se acumula sarmiento para hacer piras de más de 20 metros, en Gallucio se hacen con madera, en Nápoles los cipi con madera vieja, en Fara Filiorum Petri las farchie con cañas secas, en Mamoiada la tradición local cuenta que cuando no había fuego en la tierra fue San Antonio a los infiernos a buscar el cochinillo que le habían robado los demonios y trajo el fuego prendido en sus vísceras, en Novoli se hace una gran hoguera, etc. (Rivera 1988).

Se hacen hogueras desde Epifanía (el tiempo en que finalizan las fiestas). Hay grandes fogatas en Goito y en Tarcento se cuenta que las hogueras recuerdan a las que hizo María para secar los pañales del Niño o las de los Reyes Magos para iluminar el camino. Aunque también se hacen para quemar a la Bofana, la vieja, un muñeco hecho de trapos y otras cosas. Gran pira en Lezzeno el 18 de marzo para quemar la vieja. Se quema en Cuaresma o en San José en varias poblaciones como Roca San Casciano, Modica, Castel del Rio, y en la Toscana, en Verona, etc. A veces de la vieja serrada salen dulces o frutos secos o la rotura de la piñata. Un fantoche contenedor de dones. Pero también está aquí aludido el sacrificio, la matanza del cerdo, o la muerte del rey del Carnaval. En Lula, sobre las cenizas del fuego de San Antonio se planta la cucaña, símbolo evidente del retorno primaveral (Rivera 1988). 
Es ésta una muestra de datos selectiva con intención de revitalizar de algún modo las empolvadas dos teorías clásicas del fuego solsticial y el fuego lustral también asumidas por Mircea Eliade entre otros. La del fuego solsticial interpretaba que con las hogueras se acompañan el fin del invierno y el comienzo de la primavera, en ellas se quema la vieja, se mata la muerte, la leña se consume para que vuelva la vida vegetal, las plantas verdes. Las hogueras remedan al sol y también le ayudan a recuperar brillo y calor. Se celebra el retorno de la vegetación y se intenta provocarlo mágicamente (Cardini 1984). Por otra parte, el fuego lustral que acompaña este paso, como los del Beltane celta, es el que purifica lo viejo, el que convierte en ceniza trastos sobrantes y por el que pasan las personas saltando sobre él para librarse de males adquiridos y para prevenir males futuros y en torno al cual y por el cual pasan los animales para ser purificados tras la insana estabulación invernal (como de forma semejante se hacía en las fiestas Consualia romanas. Cf. Caro Baroja 1965)

Los ritos del fuego entre los pueblos europeos están, como ya advirtió Frazer, distribuidos a lo largo del año y por tanto parecen seguir al sol más allá del invierno y más allá de sus estados débiles, transitando por equinoccios y solsticios. O más bien siguen los ciclos diurnos marcando invariablemente atardeceres a la espera de un nuevo amanecer. Esa primordial regularidad se subraya en determinados tiempos a lo largo del año, sin duda. Mientras que en la función lustral el fuego no es elemento único. La etnografía en los mismos pueblos europeos proporciona abundantes datos sobre el uso lustral de las aguas, de los barros, de los vientos, del aceite, del vino, de determinadas piedras, etc., etc. Dicho de otro modo, no hay mayor razón para reducir el sentido de los ritos del fuego por San Antonio a una función cosmológica - por trascendente que parezca- y como otros muchos elementos en los rituales están cargados de significados múltiples de los cuales deben dar cuenta los estudios particulares en cada contexto.

Esa riqueza de significado es la que sobresale una vez que se exponen los datos etnográficos. He aquí algunos:

- En La Rioja, el ciclo de las hogueras comienza en Todos los Santos y acaba en Semana Santa. Reciben el nombre de marcha, marcharas o marchos. En Alfaro, Alcanadre, Villamediana, se hacen a la puerta de las casas y se asan patatas. En Villaverde se hace en la ermita y se come morcillón de matanza, hecha días antes (Elías 1985).

- En la Ribera de Navarra, se hacen la noche del 16 de enero, con gavillas de leña, cueros inservibles y se asan patatas en las brasas. Estas brasas las saltaban las mujeres y se las llevaban luego a casa porque eran buenas para la piel, los hombres pasaban las caballerías por las cenizas aún calientes. Había múltiples hogueras casi siempre delante de las casas de los labradores ricos, donde se repartían 
tortas, pan y vino. Bendición del ganado con el tizon navideño encendido por el mango y con él recorriendo los establos diciendo "San Antón os guarde".

- En Navalvillar de Pela. A partir de la 8 de la noche del 16 de enero en las esquinas de las calles más antiguas, cuando sale el abanderado con el tamborilero, hay hogueras enormes que se atizan sin parar. La leyenda dice que los jinetes cristianos (¿o moros?) a galope invadieron el pueblo llevando antorchas, incendiando casas y pajares y produciendo aquí y allá hogueras a la vez que lanzaban gritos guerreros. Existe una interpretación contraria. Se trataba de un engaño que hicieron los peleños a los moros, con hogueras y dando vueltas por el pueblo a caballo con grandes camisas blancas y aumentando la altura con gorros en punta para dar apariencia de gente de gran tamaño. La fiesta se llama la Encamisá. Se hacen carreras por tres veces siguiendo el recorrido que marcan las hogueras.

- En Fresnedoso de Ibor, los quintos acompañados de hombres y niños acarrean leña el 16 de enero a la plaza mayor. A las 12 de la noche la lumbrinaria se enciende y hay salvas y cohetes. El fuego debe durar encendido toda la fiesta. Llegan enormes cargas de encinas. La gente grita: “¿Dónde están esos quintos?” Al terminar la descargar las madres les obsequian y luego ellos invitan a cabrito ya cocinado. La procesión del santo pasa por la lumbre (Extremadura festiva).

- En Baeza, Torreperogil, Torres, Arquillos, Cárchel, etc., se conocen como lumbres de San Antón. Encendidas al atardecer en huertas, cortijos y caserías y todos los lugares donde hay ganado. Se espera que ahuyenten las enfermedades y protejan a los animales. Se emplean materiales de la poda del olivo, los ramones, a los que se añaden capachos viejos para el prensado empapados aún en aceite. Los niños salen al campo los días anteriores. Hay peleas entre las calles y los barrios por el ramón y asaltos a los almacenes de los rivales. Competencia por la mejor lumbre. Además petardos, mixtos, buscapiés, etc. Se baila el melenchón en la plaza junto a la hoguera, la danza rodea la lumbre o en un llano cerca de ella, prendidos de la mano. Coplas de letra picante. Se queman muñecos alegóricos colocados en lo alto. Comida y bebida, palomitas de maiz, rosetas, tapas de embutido, y calabaza batatera, etc.. Concursos de lumbres. En Jaén ciudad, en los barrios de Magdalena, San Felipe, Alcantarilla, y otras se hacen la noche del 16 al 17. En Úbeda se ponen las hogueras en las plazas, se saltan y junto a ellas se toman churros con chocolate.

- En Fia Faia (pirineo aragonés), niños acompañados de adultos recogen hierba que dejan secar y con la que confeccionan antorchas en Navidad, luego las amontonan en una hoguera y saltan sobre ella. En el Valle de Chistau hacen esquiladas saliendo al monte y se hacen hogueras en Ainsa. Hay hogueras en muchos pueblos por San Sebastián.

- En Casa Bajas (Ademuz), la noche del 16 hay más de un centenar de hogueras como primer acto de fiestas. Se come carne a la brasa, vino y matojos que es un dulce de anís. La noche de las hogueras comienza con volteo de campanas. Cada grupo de vecinos. Las saltan los chavales con los chalecos y las esquilas para hacer ruido.

- En Poyo Largo, los mozos y los niños recogen leña y la llevan a una elevación llamada La Cuerda, junto al pueblo, donde se deposita. Al atardecer, las cuadrillas, con cencerros y canciones, van a encenderlas. "San Antón como era viejo,...", "Una vieja muy revieja...." 
- En Minglanilla, se ponen hogueras en las calles. Se cena junto a ellas. Se tiran harina unos a otros.

- En Villarrubia de los Ojos, se hacen hogueras la víspera por la noche y quedan encendidas a las puertas de las casas; se hacen carreras y hay reparto del puñao de garbanzos y cachuetes.

- En Estercuel, Aguaviva y otros pueblos, se hace la representación de Las Tentaciones: una chica le tienta, el santo se refugia en la cabaña de leña, llegan los diablos que la prenden fuego. La barraca se prende al final de la representación. También en Estercuel se llama la Encamisada. Recogen aliagas el día anterior y al atardecer se hacen unas 15 hogueras con concurso. Se va a buscar a la iglesia el estandarte del santo y con él se procede a encender la primera. Hacia las 8 se organiza la encamisada. Luego fiesta y baile. Al día siguiente limpian la calles para la procesión. 7 parejas portan hachones y acompañan las imágenes de los santos.

- En Osaje y Trasobares, la víspera se encendían hogueras en plazas y calles. Se comen patatas asadas, tostadas de pan y chorizo, etc. Se creía que a las caballerías de los que aportaban leña no les daría torzones. Se cantaban y bailaban los chimilindrones.

- En Tomelloso, la noche del 16 de enero se reunen trastos viejos, gavillas de sarmientos, cepas, etc. para hacer las hogueras. Se asan productos de matanza,... En Almagro, las hogueras reúnen a los vecinos. Se come somallao, patatas asadas, chorizos, limoná. En Villar de Cañas, se hacen luminarias con los trastos viejos que no sirven. Vino y tostones. Las saltan y en la actualidad se asa carne.

- En Villafranca de los Caballeros, se hacen hogueras la víspera por diversos puntos y especialmente delante de la ermita. Se les llama gueras. En Jaraguas también la víspera, se encargan gupos de vecinos y llegan a formarse hasta unas 20 en total. Hay baile con disfraces grotescos.

- Artá. Hogueras por toda la villa, canciones pícaras.

- Torre de Juan Abad. Luminarias, cante y baile. Invitaciones a los que pasen por allí.

- En Loscos, se hace una hoguera en cada barrio y sobre todo la del peirón de San Antón y en la plaza. La leña la aportaban los vecinos. Se asan chorizos, longanizas, güeñas. Por la mañana antes de encenderlas daban tras vueltas en torno al peirón con caballerías y animales y luego se hacía la bendición

- En Visiedo, se encendían hogueras en todos los barrios y se bebía y se comía tortas de cañamones. Algunos daban tiros de pólvora con trabucos y se cantaban canciones. Ya de madrugada se jugaba en las tabernas a la morra, los de una hoguera contra los de otra, lo que se consumía en ellas.

- En Galicia, también se hacían hogueras por San Antón, en torno a las cuales se dan vueltas. Hay una capilla en un otero cerca de Verín, donde van los mozos la víspera con hachas de paja a la verbena y al día siguiente hacen las hogueras junto a la capilla y se asan allí chorizos. Van máscaras antiguas como el cigarrón.

- En Almarcha, cada familia reúne paja y material de desecho acumulado todo el año: espuertas, serones, capachos, sillas, etc., y se atiza la luminaria, se comen tostones y se danza alrededor cogidos de la mano. Los jóvenes cuando decaen las propias van a las más grandes ajenas y forman corros y cantan canciones con estribillo. 
- En Cañete, se hacen por calles con lo viejo de cada casa, cuévanos, espuertas, horcas de madera, etc., añadida a leña seca y enseres para tirar. Chicos y chicas se reúnen y cantan canciones alusivas. Luego recorren el pueblo hasta que se consumen todas las hogueras.

- En la provincia de Zaragoza, son actividades comunes de calle en las que se participa sin distinción de status, sexo o edad... Son hogueras de aveniencia entre vecinos por barrios, los chicos las recorren y las brincan. Cuadrillas de mocetes van pidiendo leña a las casas: "Leña para San Antón y si no tozolón". Cuando no se da leña la amenaza es desear la enfermedad del ganado. Se trata de leña menuda, romero, aliaga, sabina, tomillo, sarmiento, caña de río, pinocheras. De ésta se encargan las mujeres de las casas que van juntas al monte a proveerse de ella, mientras que los hombres se encargan de la leña gorda, de oliveras y carrasca. La leña ya reunida en las casas es la que piden las cuadrillas para las hogueras, que a veces roban si no se la quieren dar. Además se queman toda clase de objetos que se acumulan durante el año, "lo viejo", que se iba acumulando en el corral y se limpiaba éste justo para antes de las hogueras. O bien se prepara un sanantonero, un tronco grande de cuando se remoldaban los olivos (Belchite), o muebles, libros, papeles, telas, etc. "Para San Antón, trastos al montón". Aún está reciente la matanza del cochino y se aprovecha la ocasión para probar los embutidos. Para la noche de San Antón se deja lo mejor, la morcilla del cular (Monegros), el morcillón (Ribera alta y baja, Calatayud), el morquerón (Prepirineo), y además patatas, chorizo, longaniza, orejas, a veces la cabeza, migas y buen vino. Y para finalizar, las mujeres preparan chocolate. Comensalidad para favorecer la unión. Los vecinos al sentarse alrededor de la hoguera a comer imitan a la familia cuando se reúne en la mesa. Antes de retirarse a las casas recogen la ceniza para echarla a los campos para fertilizarlos. La brasa se utiliza para mantener caliente el hogar durante la noche. Y de cuando en cuando se atiza la lumbre para que el humo entre en los patios, gritando "humo a San Antón".

- En Huesca, se encienden hogueras principalmente por San Juan, San Antón y San Sebastián y también otros santos como Santa Águeda, San Vicente, San Quilez, y en Navidad. Acarrear leña es tarea común, aunque cuando escaseaba o era dificil obtenerla se dejaba en manos de los jóvenes que frecuentemente la sustraían, sabiendo que los dueños no podían enfadarse ni pedir cuentas por ello. Y se requería que alguien pusiera tractor o caballería para acarrearla. Se mantenía toda la noche encendida hasta que a la mañana siguiente pasaba la procesión sorteándola mientras las llamas hacían difícil el paso, aunque se hace más vivo el fuego en honor del santo (en San Sebastián). Y en torno al fuego, la comensalidad. Asociadas a la fiesta de San Antón se hacían las esquilladas y las plegas.

Cabe añadir muchos más datos, aunque de lo expuesto parece derivarse la necesidad de reconocer que el relieve de estas formas festivas responde a un esquema básico común pero es rico en reflejos, perfiles, caras, tonos, colorido.

1. Una hoguera es ante todo reflejo y acción de las entidades sociales. Las casas, las calles, los barrios, el pueblo la toman como seña y señal de presencia pública. El indicador de presencia social en el contexto y proce- 
so de la fiesta. El nivel y configuración de esa presencia dice mucho de la vida social de cada población. Además de visibilidad, calor. En la fiesta invernal de San Antón, de San Sebastián, el calor de la hoguera se transfiere y se transforma en el calor de la vida social. Una y muchas hogueras dan a la divisibilidad y a la unión de las comunidades perfil e imagen. Y el fuego como elemento a manipular permite la continuidad-discontinuidad y en todo caso la comunicabilidad. A veces el fuego se transmite desde algún punto al resto. Señala un centro y los otros núcleos comunicados con él. O fija una jerarquía con sus posiciones diferenciadas. $\mathrm{Y}$ en las frías noches, el conjunto de ellas muestra la presencia mutua de unas y otras comunidades dentro de horizontes de proximidad. La geografía local de las hogueras no sólo reproduce planos y mapas sino que los reconstruye. Hay territorios, campos que en la vida cotidiana son imperceptibles y que aparecen con las hogueras. En ocasiones emergen como lugares de agrupación estable para una convivencia larga de toda una noche, en otras se conforman como puntos de un recorrido interior, una ronda y una rueda de desplazamientos que favorece los encuentros sociales y activa relaciones descuidadas.

2. Como otras muchas fiestas, pero en tiempos de frío, las hogueras sacan a la gente a la calle. Ya no es el fuego del hogar, sino el fuego fuera del hogar. A su modo también un fuego doméstico. Algo más arriesgado pero mantenido bajo control. Más voluminoso y más violento que el de los hogares, alimentado con más materiales que los que se usaban para el fuego cotidiano puede llegar a convertirse, por su mismo afán de fuego ceremonial cuya visibilidad y atracción se logra a base de tenerla bien abasteci$\mathrm{da}$, en una fuente de peligro. Existe un volumen crítico que no se puede sobrepasar y debe ser controlada teniendo en cuenta la fuerza y dirección del viento. En muchos aspectos la ejecución y el mantenimiento de una hoguera es una prueba a superar. Y requiere cierto adiestramiento. Los aspectos técnicos pueden llegar a comportar toda una maestría. Canals es un ejemplo paradigmático. Los materiales que se reúnen, sus tipos, su distribución, la composición, la veste vegetal que la recubre, todo ello es parte de un saber técnico para hacer humo y fuego en fases de comienzo balbuceante, prendimiento, hasta que las llamas se hacen con la estructura toda que pierde primero la estabilidad y luego la forma y hasta la entidad misma. Finalmente quedan las brasas. El proceso acompaña al paso de la noche al día y lo que es más destacable está asociado (lo activa y a la vez lo refleja) al proceso de agrupamiento y dispersión social. La reunión en torno a las hogueras sigue fases de comienzos balbuceantes, entrar en calor, llegada de más gente, sociedad densa, bullicio, y luego desagregación progresiva. Finalmente junto a brasas y cenizas algún rezagado y nadie.

3. Materiales y restos: por un lado las hogueras se hacen principalmente 
de leña gruesa y menuda, por otro lado de desechos, "de lo viejo" intencionadamente acumulado para este destino a lo largo del año. De grandes leños especialmente seleccionados y de maderos y palos residuales de la actividad agrícola, de herramientas y útiles de corral ya sin función y de mobiliario desusado o deteriorado del hogar. Esta doble caracterización sitúa a las hogueras entre el derroche y la limpieza. No es por ambigüedad sino por coincidencia de contrarios. La leña ha sido en muchas sociedades campesinas europeas durante siglos un recurso estratégico. El derroche de ella era un signo de riqueza. Entre los datos anteriormente expuestos se hace notar que las hogueras en algunas poblaciones se ponían delante de las casas de los ricos porque la desigualdad se traducía entre otras cosas en las aportaciones de materiales para ser quemados en ellas. Hay un doble sentido en las hogueras como destrucción o como purificación que parece venir determinado por la naturaleza de los materiales aportados. Si se quema leña, pudieran ser potlachts, piras en las que los bienes acumulados se destruyen transformados por prestigio, o pudieran ser ofrendas de bienes valiosos presentados a los seres sobrenaturales por gratitud, para congraciarse con ellos o para poner bajo su cobijo a las personas y sobre todo al ganado. Y si se queman restos y desechos, bien pudieran ser mecanismos de ajuste de los sistemas ecológicos, procedimientos de fin de ciclo de uso o de disolución de restos... para permitir de esa forma la secuencia regular de los nuevos ciclos. En esta duplicidad se advierte también una doble dirección: el fuego y el humo puede ir dirigido a lo alto o puede llegar también a los seres terrestres que andan en torno. Hay además utilidades varias: las brasas y las cenizas aún son aprovechadas en casa y en el campo. Y el fuego y el humo tienen efectos de desparasitación en el ganado. Tales sentidos no pueden tomarse como esenciales en la fiesta sino como cambiantes en el tiempo y susceptibles de mezclas y de transformaciones (como del mismo modo ocurre en otros rituales). La leña no ha mantenido a lo largo del tiempo el mismo valor, ni por supuesto lo ha tenido igual en poblaciones con bosques y poblaciones del llano cerealista,... leña menuda procedente de la poda es en muchos casos residual, etc. Las explicaciones puramente funcionalistas del fuego ritual no eliminan el carácter simbólico del fuego ritual. No es que este carácter cobre relieve cuando las acciones rituales se mantienen, pese a que sus utilidades cambian. Más bien este carácter refuerza y garantiza la ejecución regular de acciones "útiles" y sobre todo alienta y anima la necesaria vida social. También se queman las envidias, riñas, malos sentimientos — dice Rivas (1986) - que han ido surgiendo entre vecinos, de modo que ese día se habla de todo el mundo.

4. En realidad son múltiples las funciones de las hogueras y enumerarlas daría listados en parte similares pero también distintos en unas o en 
otras poblaciones. Se hace obligado atender además no sólo a las funciones del fuego, sino a los objetivos buscados desde las formas, extensión, altura, disposición de materiales, etc... Las hogueras no sólo queman montones de leña, madera, palos, etc. Y según sea el material, como ya se ha dicho, se pondrían de manifiesto unas u otras funciones. Queman también figuras, peleles, muñecos de paja, cabezas de cartón o trapo, etc., representaciones de referencias más o menos explícitas a veces al mal en general o al mal en particular. Se queman grandes volúmenes, montones de tamaños diversos, pequeñas acumulaciones, composiciones de altura, etc. Las hogueras son signos de enorme carga polisémica. No es más el número, el material o la figura que la propia hoguera que significa. Quien quema va asociado a qué quema y el qué se quema puede no ser algo concreto o físico -sino algo que está meramente aludido o incluso no explícito- y el fuego como acción parece tener poder o capacidad para afectar al tiempo pasado y al tiempo futuro, trascender a ese tiempo delimitado, a esos instantes fugaces. El tiempo mismo puede quedar afectado por el fuego: se quema el invierno y se quema el tiempo.

5. Las hogueras se miran y hacen formar corros en torno a ellas. Pero también se dan vueltas alrededor, se rodean andando o bailando o se pasa por encima de ellas y se saltan. Además se come, se canta, se charla, se juega, se corteja, se riñe,... todo al lado.

- En la provincia de Zaragoza, de las hogueras de S. Babil y Santa Águeda se dice que dando tres saltos por encima la mujer conserva su fertilidad, y de la San Antón se cree que si el dueño de la caballería enferma da tres vueltas alrededor rezando alguna oración el animal curará de su mal. También se dan tres vueltas para evitar que las caballerías caigan enfermas, para ello hay que dar una vuelta por cada animal de carga o de tiro. Ha de hacerlo el marido (Rivas 1986).

- En Muel, Mezalocha, Miedes, etc., por cada caballería y animal se echa un fajo de leña a la hoguera y se repite: para que San Antón los guarde. En Fuentes de Ebro todos los animales han de pasar por encima de las cenizas, en Tierga, Las Cuerlas, Tabuenca, Chiprana, etc, hay que dar tres vueltas alrededor. Y muy comúnmente hay que saltar tres veces la hoguera. Cuando se trata de animales es el hombre el que salta ("San Antón, consérvame el jamón"). Cuando se trata de la protección de la familia es la mujer (Rivas 1986).

Los datos etnográficos sobre estas acciones podrían ser otra vez abundantes. Si bastan los aportados es por ilustrar en concreto algunas de las formas festivas de vivir las hogueras. Es obvio, y sobre todo porque es intencional y explícito, que se trata de actos sociales. Y habría que añadir que dan imagen a la vida social, no sólo en el sentido ya apuntado de hacer visibles a las entidades sociales sino que el obligado dibujo de la situación de las gentes en torno a la hoguera quiere ser tomado literalmente como 
una concentración y metafóricamente como reunión, cohesión, calor social. En muchos aspectos las hogueras son fiestas paradigmáticas y en estos también. Las hogueras refuerzan la redundancia. Reúnen y unen a las gentes. Pero sobre lo explícito están aún recargadas de significación por medio de ciertas formas en las que la reiteración se camufla ya como danza ya como juego: dar vueltas, saltar. Tales formas han sido interpretadas como reproducciones de movimientos cosmológicos: el sol girando incansablemente. Y también el año como ciclo que va girando. Entre los sorprendentes y maravillosos efectos de estos giros está incluso la figuración de que el cosmos seguirá así siendo una serie de movimientos regulares, ordenados. Personas y animales sentirán así los beneficios de la regularidad, la armonía y el orden. Las vueltas y los saltos no dejan de ser actos sociales para efectos sociales y se pretenden también que sean por el fuego que rodean y sortean actos cosmológicos con efectos protectores. En todo caso antes y ahora no fueron los únicos motivos fuertes de la fiesta, no menos que la diversión, el humor, el canto individual y a coro, la comensalidad, la bebida, la degustación de los embutidos a la brasa,... y todas las otras pasiones que el fuego también aviva.

Las hogueras se hacen la víspera, las bendiciones el día de la fiesta. Las hogueras se hacen con vegetales, con yerbas secas, madera y leña, las bendiciones se destinan a los animales. Las hogueras llevan el fuego controlado a los espacios centrales, las bendiciones rocían con agua a quienes se acercan a los recintos sagrados. Las hogueras ordenan la concurrencia de gente por con-centración en torno a ellas, las bendiciones ordenan a la gente y sus ganados en filas. Las hogueras animan a la diversión, las bendiciones son actos religiosos de una imposible seriedad. Las hogueras a veces requieren especialistas, pero por lo general todo el mundo se considera oficiante. Las bendiciones no tendrían efecto sin el oficiante legitimado. En el programa se suceden pero no parece que la secuencia tenga alguna conexión lógica. Aunque, por supuesto, las bendiciones también son actos de vida social.

La etnografía revela algunos de los sentidos que las poblaciones dan a las bendiciones:

- El día de San Antón en casi toda Huesca no se hacía trabajar a las caballerías porque era su patrono. Y además por ese motivo se les daba buen pienso. Algunos ni siquiera sacaban los animales de la cuadra. Se creía que el incumplimiento de esa norma acarrearía males. "Hubo un señor que dijo que eso eran tonterías y cogió el caballo de la casa y quiso ir a abrevar y cuando bajó la costera se le partió la pata al caballo". "Se bendecían las caballerías y la gente a lo mejor trabajaba pero las caballerías no". En Torralba de Aragío ahora se bendicen los tractores y no se va a trabajar con ellos (Lisón Arcal 1986). 
— "Por San Antonio de enero, huelga la mula y trabaja el mulero". Montemayor de Pinilla (Valladolid). Son fechas de pocas faenas agrícolas por el clima. Y propicias para reuniones y vida comunitaria en hilorios, filandones, etc. (Alonso Ponga 1983).

- En La Rioja no se cargan las caballerías.

- El patronazgo lo ejerce el santo sobre todos los animales, y de manera especial sobre cerdos, y gallinas como base de economía ganadera (sic). Se le encomiendan los animales cuando están enfermos y si sanan se le lleva huevos o lacón. Además está la llamada "rana de San Antonio" que no se puede matar por que si no el santo hará enfermar alguno de los cerdos. Y es guardián de los animales. En Fornela cuentan que se apareció a unas cabras estando los pastores dormidos y las libró del peligro. Oraciones al santo contra la hinchazón de ovejas y cabras. También el responsorio de San Antonio. En algunos sitios aplicado solo contra el lobo, en otros para encontrar algo perdido, confunden los santos.

- Generalmente se bendice a los animales de labor o a los ganados y se llevan a la puerta de la iglesia. No se llevaban todos sino una representación. En Vizcaínos de la Sierra iban los mozos con los burros bien adornados, bendición y vueltas a la iglesia a la carrera. En Tudela de Duero, con caballos adornados y vueltas a la iglesia con los chiquillos corriendo detrás, luego la bendición del cura. En Mayorga o otros pueblos de Campos con burros y caballos adornados, bendición y luego cabalgadas, para terminar con relaciones. En Olmos de Esgueva se bendice la cebada que luego se da a los animales, en Bembibre se bendicen unas bollas que luego se reparten a personas y animales, en Roales de Campos las rosquillas del santo con granos de anís bendecidas en la iglesia y se comían en casa dando trozos a los animales, estas rosquillas tenían forma de muñecos, etc.

- En San Millán de la Cogolla se bendice la cebada, en Berceo los cereales. En Saturdejo y otros pueblos de la Rioja se dan vueltas a la iglesia con los animales y se le pide que les libre de la rabia. El objeto es proporcionar salud a los animales y en San Adrián de Apellaniz en particular prevenir el aborto de las yeguas. En Brieva de Cameros se metía en tiempos a los burros dentro de la iglesia para las vueltas, como en Santo Domingo de la Calzada se hacía con bueyes y mulas y carros dos días antes de la fiesta de Mayo a Santo Domingo. En Laguna de Cameros, vueltas con los caballos. En Munilla es carrera de caballos con tres vueltas al barrio de San Miguel (Elías 1985).

- En Torralba de Calatrava (se encarga la hermandad y llevan una cruz en la cara superior), en Carrión y en Argamasilla de Alba (roscas para las caballerías) se elaboran panecillos especiales que después de bendecidos comen hombres y animales; en Balsa de Ves dos filas de chicas en la procesión llevan cestos a la cabeza de pan que son repartidos a la salida de la iglesia, se elaboran con donativos de los vecinos y harina ofrecida al santo como protección para los animales; en El Hito, se reparten rolletes o caridades al final de la romería; en Pozuelo a los animales se les cuelgan en los cabezales un rosco de San Antón para que el santo cuide de ellos; en Moratilla de Meleros lo elaboran las mujeres de los mayordomos de la cofradía; En Golosalvo, se encargan los labradores de ofrecerlo al santo; en Villahermosa son los labradores los que reparten pan candeal y cañamones. (González Casarrubios 1985).

- En los panecillos del santo en Madrid aparecían impresos una campanilla, un puerco con ella al cuello o la tau del santo (Castellanos 1848; Caro 1965). Y los proporcionaban a la procesión con el rey de los cochinos los frailes de San Antón 
en la portería del convento. La romería iba a la ermita de San Antonio que estaba en el Retiro y la componían por orden: primero mozos del campo en borricos enjaezados y con caperuzas negras y puntiaguados tocando cuernas, porqueros con seis cerdos llenos de cascabeles y campanillas, luegos los machos de las piaras con esquilones y encima mozos disfrazados, luego los barracos con mantillas lujosas, con el rey de los cerdos con una corona de ajos y guindillas, y luego la chusma en burros y tocando cencerros, cuernos y tambores. Allí se proclama rey al muchacho poniéndole la corona que llevaba el cerdo. Era un zagal salido a suerte vestido de san Antón con báculo y campanilla y montado en burro hasta que llegaba allí, donde con la proclamación se montaba sobre el cerdo. Luego de eso iban al convento a que les bendijeran la cebada y la paja para el ganado y los panecillos.

Sea cual fuere el fundamento dado al patronazgo de San Antón sobre los animales está completado si no confundido en ocasiones con el de San Antonio de Padua. Y sin causar mayor trastorno incluso en algunos lugares se usa la imagen de éste para la procesión y bendición el día de la fiesta de aquel. Con ambos santos se produce una extensión de lo que la creencia identifica como protección más allá de los ámbitos específicamente humanos. Lo que las procesiones y bendiciones implican es claramente la integración social de los animales, su consideración de partícipes de la vida social. En particular los campesinos con los animales domésticos, los de labor y transporte, pero también con el ganado del que se obtiene una producción llegan a tener unos vínculos muy especiales. Tales vínculos se tienen como generales para los animales de compañía en las sociedades modernas. En realidad esta diferenciación entre sociedades tradicionales y sociedades modernas no es tan clara. Varía también la relevancia dada en distintas sociedades - y en distintos tiempos dentro de una misma sociedad- a determinados animales. Bueyes, cerdos, ovejas, caballos, asnos, mulos, perros... aparecen de modo desigual en las procesiones, mostrando así que esa "otra parte de la comunidad" engloba sólo de modo general a los animales, pero más en particular a algunos. En todos los casos suponen un trato individualizado y un conocimiento profundo de gustos, proclividades, estados de ánimo, etc. Algo de ese trato ha quedado reflejado en los datos etnográficos anteriores.

Se cruzan dos líneas de prácticas en este proceso ritual:

- Por un lado, lo que vendría siendo una "humanización" de los animales, es decir, las formas festivas incorporan con papeles activos y para situar en espacios y territorios característicamente humanos a seres que se consideran irracionales. Les incluyen en desfiles procesionales y extienden hacia ellos la comensalidad. Se trata de una integración social que parece implicar la pertenencia a la comunidad 
y que expresa el establecimiento de lazos sociales. De esta manera en el sistema de fiestas se marca tal pertenencia al facilitarles en una de ellas —al menos — visibilidad social, protagonismo. Los rasgos de esta integración social o humanización están indicados en los papeles rituales dados a los animales:

1. descanso festivo, cese del trabajo;

2. engalanamiento y adornos corporales para intervenir en la fiesta;

3. aproximación o acceso a los recintos sagrados;

4. con posiciones diferenciadas dentro de la procesión y formando parte del orden social. (En algunos sitios se distinguen estas procesiones por que el desplazamiento se produce en sentido contrario a las agujas del reloj o en sentido contrario a las salidas procesionales del resto del año);

5. receptores de la bendición y de sus beneficios no sólo como bienes de sus dueños sino por una razón social: la de patronazgo;

6. dan tres vueltas al recinto sagrado guiados por los dueños;

7. participantes igualmente de las actividades de diversión como carreras y juegos;

8. comensales del pan bendito.

- La otra línea de prácticas viene a ser un contrapunto de la anterior: la "animalización" de los humanos (Cruces 1994) como muy particularmente se figuraba en el rey de los cerdos, una procesión casi bufa en la que los que conducen a los animales parecen no distinguirse de ellos, pero también aludida por los gestos humorísticos en las carreras actuales de San Antón. Como anticipo del Carnaval la fiesta les proporciona esa posibilidad de equiparación de papeles. En cualquiera otra situación en el año sería un rebajamiento inaceptable el verse equiparados y toda una profanación el frecuentar espacios tan venerados, pero en esta fiesta ambas cosas están neutralizadas y no tanto como una trasgresión - como puede aparecer en las farsas carnavalescas - sino como un ejercicio de domesticación, que tanto puede querer decir control como familiaridad. Al fin y al cabo las bendiciones mantienen la posición superior del oficiante (alter ego del santo) y junto al cual se sitúa a los animales siguiendo el modelo iconográfico del santo con el cerdo a sus pies. Eso les confiere aún cierta formalidad pero el protagonismo otorgado a los animales a su modo conlleva cierta inversión de papeles. Los humanos no son esta vez los bendecidos. Y tampoco propiamente los focos de la atención social. Por un lado los adornos de las caballerías a veces exuberantes (como en Navalvillar de Pela), por otro lado las peculiaridades de los 
animales incluido el exotismo de la especie dejan en la sombra a sus acompañantes que por esta ocasión quedan en el segundo plano. Las filas formadas en las áreas rurales compuestas por reses de ganado lustrosas y por las adecentadas bestias de labor y transporte dan una dignidad peculiar a esa presencia pública hasta el punto de que asimila al conjunto a los humanos acompañantes. Mientras que en las fiestas urbanas los animales de compañía parecen mostrarse en público con la superioridad que les da el saberse objeto del capricho de sus amos. La "caravana de animales" (Cruces 1994) llena uno y otro escenario como en los mundos imaginarios en los que los animales se mueven a sus anchas. Caben no obstante variados sentidos dependientes de contexto y que de hecho son aprovechados para los más variados fines personales, sociales, políticos, etc. (La caricatura, el guiño crítico, la extravagancia, la competencia,... y otras muchas actitudes se hacen presentes en estos desfiles).

Posiblemente no se trate de otra animalización que aquella que consiste en recrear imágenes de los animales inevitablemente antropomorfas. En algún sentido esas dos líneas se encuentran representadas en la hagiografía del santo. Por un lado las bestias salvajes acabaron acercándose a él y aportándoles su ayuda, por el otro los demonios se transformaban en las más horribles bestias para atemorizarle, aunque el santo siempre se mantuvo imperturbable.

Finalmente, existen algunas evidentes analogías entre las prácticas que se realizaban y se realizan con las hogueras y las que se llevan a cabo con las bendiciones. Es posible pensar que las acciones de purificación y protección del ganado que las poblaciones en algún tiempo hicieron por medio de las hogueras luego las repitieran o sustituyeran con las bendiciones en el nombre del santo. "Dar vueltas" es una de esas prácticas que hombres y animales realizan en torno a la hoguera y en torno a la ermita. Pudiera ser que la fiesta de San Antonio hubiera cristianizado alguna otra anterior. Aunque definitivamente esto no es tan relevante. Más aún lo debiera ser que unas y otras prácticas se hayan configurado como formas festivas al amparo de una advocación, San Antonio, presentado como el señor del fuego y el protector de los animales. Unas formas festivas con las cuales las poblaciones dan consistencia y redefinen regularmente las complejas y cambiantes relaciones entre la Naturaleza y la Cultura. 


\section{BIBLIOGRAFÍA CITADA*}

Alonso Ponga, J. L. 1981. "Manifestaciones populares en torno a San Antón en algunas zonas de Castilla y León”. Revista de Folklore 2: 3-10.

Ariño, A. 1991. El foc i la roda del temps. Figures d'una festa mediterrània del cicle agrari. Valencia: Palladio.

Blázquez, J. M. 1998. Intelectuales, ascetas y demonios al final de la Antigüedad. Madrid: Cátedra.

Brown, P. 1988. The Body and Society. Men, Women, and Sexual Renunciation in Early Christianity. Nueva York: Columbia University Press.

Burke, P. 1978. La cultura popular en la Europa moderna. Madrid: Alianza Universidad.

Cardini, F. 1984. Días sagrados. Tradición popular en las culturas euromediterráneas. Barcelona: Argos-Vergara.

Caro Baroja, J. 1965. El Carnaval. Análisis histórico-cultural. Madrid: Taurus.

Castellanos, S. de. 1848. "Costumbres españolas: De la romería titulada las vueltas de San Antón". Museo de las familias VI: 19-20.

Ceballos, B.A. de. 1994 [1759]. Vida y milagros del Grande San Antonio Abad. Barcelona.

Cruces Villalobos, F. 1994. "Símbolos en la ciudad: la caravana de animales". Revista de Dialectología y Tradiciones Populares 49: 39-70.

Christian, W. A. 1978. Religiosidad Popular. Estudio antropológico de un valle español. Madrid: Tecnos.

Christian, W. A. 1991. Religiosidad local en la España de Felipe II. Madrid: Nerea.

D'Alviella, G. 1956. The Migration of Symbols. Nueva York: University Books.

Elías, L. V. 1985. "La fiesta de San Antón en La Rioja". Revista de Folklore 60: 183-189.

Fernández Chamón, A. 1983. "La fiesta de San Antonio Abad en Navavillar de Pela". Narria 25-26: 42-47.

Ferrando Roig. J. 1950. Iconografía de los santos. Barcelona: Ediciones Omega.

Frazer, J. G. 1969 [1922]. La rama dorada. México: Fondo de Cultura Económica.

García Gainza, C. 1986. La escultura romanista en Navarra. Pamplona: Gobierno de Navarra, Educación y Cultura.

González Casarrubios, C. 1985. Fiestas populares en Castilla La Mancha. Ciudad Real: Junta de Comunidades de CLM.

Grace Sill, G. 1975. A Handbook of Symbols in Christian Art. Nueva York: Macmillan

Janer Manila, G. 1999. Les festes llunyanes. Palma: J.J. de Olañeta.

Lis Quibén, V. 1980 [1949]. La medicina popular en Galicia. Madrid: Akal.

Lisón Arcal, J. C. 1986. Cultura e identidad en la provincia de Huesca. Zaragoza: Caja de Ahorros de la Inmaculada.

Mâle, E. 1958 [1898]. L'art religieux de la fin de Moyen Age en France. París: 2 vols.

Monferrer, A. 1993. Sant Antoni, sant valencià. Valencia: Consell Valencià de Cultura.

Navarro, J. 2002 [1683]. Vida y milagros del príncipe de los anacoretas, padre de los cenobiarcas, nuestro padre San Antonio Abad, el Magno. Barcelona. (Reproducido en Palacín Zueras).

Palacín Zueras, M. C. 2002. Vida del gran San Antonio Abad. San Antón: casas antonianas..., ermitas, devociones y fiestas al santo. Huesca: La autora.

Rivas Rivas, A. M. 1986. Ritos, simbolos y valores en el análisis de la identidad en la provincia de Zaragoza. Zaragoza: Caja de Ahorros de la Inmaculada.

* Además, Guías de Fiestas y páginas web de muchas de las poblaciones citadas. 
Rivera, A. 1988. Il mago, il santo, la morte, la festa. Forme religiose nella cultura popolare. Bari: Edizioni Dedalo.

Sebastián, S. 1994. Mensaje simbólico del Arte Medieval. Madrid: Ediciones Encuentro.

Sánchez Domingo, R. 2004. La Encomienda de San Antón en Castrojeriz. El derecho de asistencia en el camino de Santiago. Gijón: Trea.

Vorágine, S. de la. 1982. La leyenda dorada. Madrid: Alianza.

Wirth, J. 1989. L'Image Medievale. Naissance et developpments (VI-XV siècle). París: Meridiens Klinchsieck.

Fecha de recepción: 16 de diciembre de 2008

Fecha de aceptación: 5 de febrero de 2009

Mis agradecimientos al Ayuntamiento de Canals y la Concejalía de Cultura cuya invitación incitó la realización de este ensayo. Además, ha permitido que sea publicado aquí. 